\title{
High Temperature Gas-Cooled Reactor Projected Markets and Preliminary Economics
}

The INL is a

U.S. Department of Energy National Laboratory

operated by

Battelle Energy Alliance

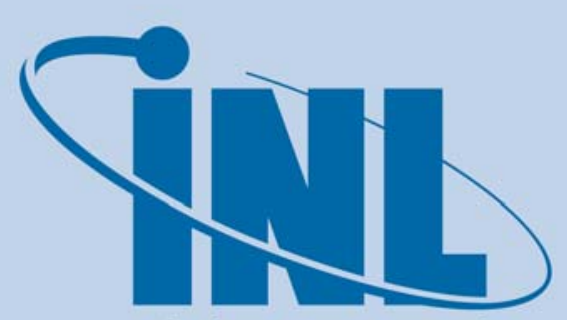

Idaho National Laboratory

August 2010

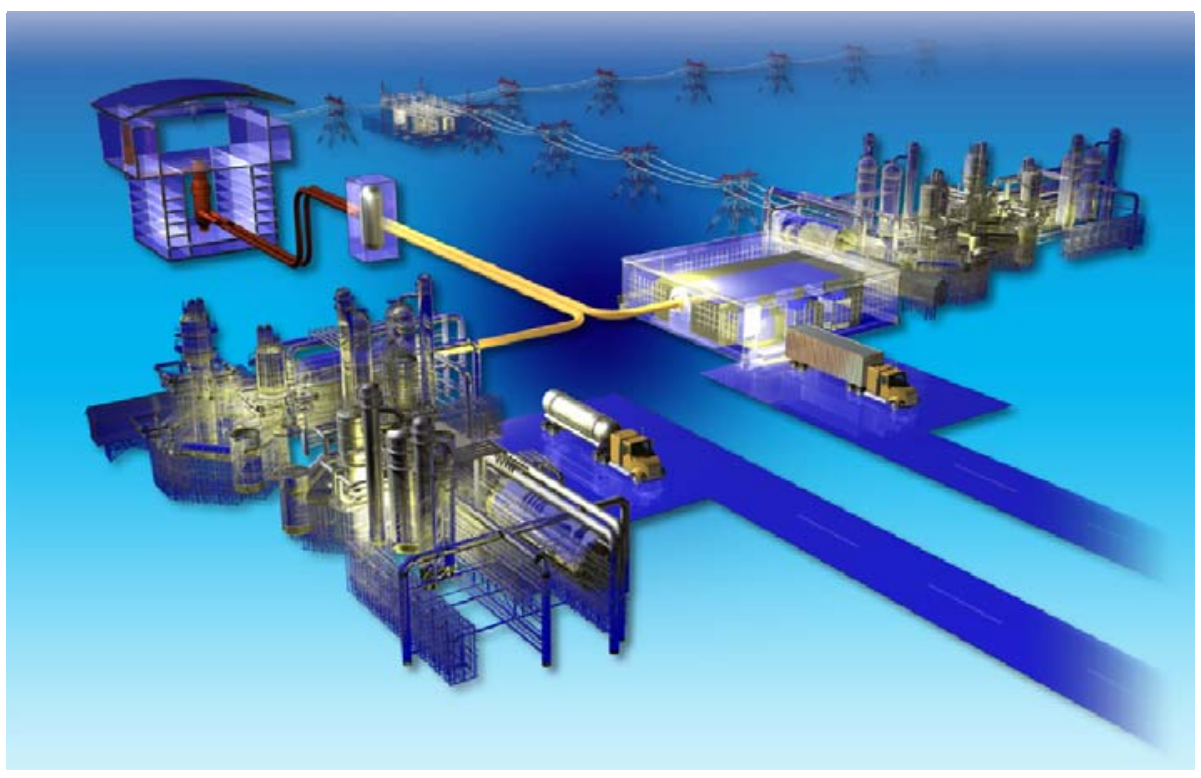




\section{DISCLAIMER}

This information was prepared as an account of work sponsored by an agency of the U.S. Government. Neither the U.S. Government nor any agency thereof, nor any of their employees, makes any warranty, expressed or implied, or assumes any legal liability or responsibility for the accuracy, completeness, or usefulness, of any information, apparatus, product, or process disclosed, or represents that its use would not infringe privately owned rights. References herein to any specific commercial product, process, or service by trade name, trade mark, manufacturer, or otherwise, does not necessarily constitute or imply its endorsement, recommendation, or favoring by the U.S. Government or any agency thereof. The views and opinions of authors expressed herein do not necessarily state or reflect those of the U.S. Government or any agency thereof. 


\section{High Temperature Gas-Cooled Reactor Projected Markets and Preliminary Economics}

August 2010

Idaho National Laboratory

Next Generation Nuclear Plant Project

Idaho Falls, Idaho 83415

Prepared for the

U.S. Department of Energy

Office of Nuclear Energy

Under DOE Idaho Operations Office

Contract DE-AC07-05ID14517 

Next Generation Nuclear Plant Project

\section{High Temperature Gas-Cooled Reactor Projected Markets and Preliminary Economics}

INL/EXT-10-19037

Revision 0

August 2010

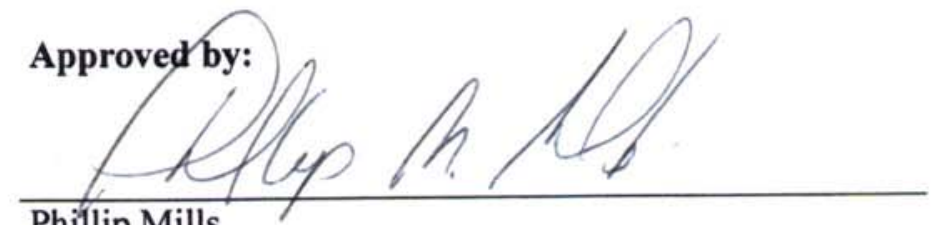

Phillip Mills

NGNP Project Engineering Director

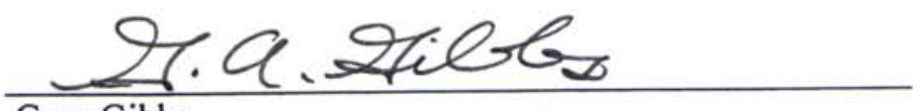

Greg Gibbs

NGNP Project Director

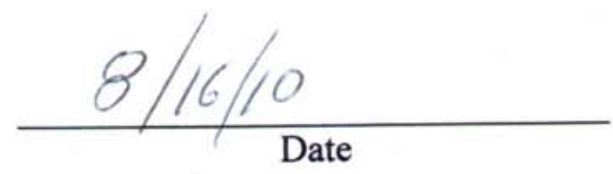

$\frac{8 / 16 / 100}{\text { Date }}$ 



\section{EXECUTIVE SUMMARY}

The NGNP Project is developing and enabling the initial commercial deployment of the high temperature gas-cooled reactor (HTGR) technology to supply high temperature process heat to industrial processes as a substitute for the burning of premium fossil fuels, such as natural gas. Commercial applications for HTGR technology that have been evaluated by the NGNP Project include electricity generation, supplying steam and high-temperature gas to a wide range of industrial processes, and the production of industrial gases (hydrogen and oxygen) for use in petrochemical, refining, coal-to-liquid fuels, chemical, and fertilizer plants. As a non- $\mathrm{CO}_{2}$ emitting substitute for the burning of fossil fuels, the HTGR can offset significant quantities of industry-generated $\mathrm{CO}_{2}$ emissions. The use of the HTGR technology as an energy substitute for natural gas in many of these applications and for conversion of coal to synthetic fuels and chemical process feedstock improves the security of the U.S. energy supply by reducing reliance on imports, reducing the energy price volatility that has been experienced over the last few decades (e.g., wide swings in the prices of oil, natural gas, and coal), and extending the life of nonrenewable energy resources for use within more productive and efficient applications where no current alternatives are available.

Market studies have identified a large market potential for the HTGR technology. The highest priorities include the displacement of natural gas and other hydrocarbons for process steam/cogeneration applications (e.g., petrochemical production, petroleum refining, and ammonia production), enhanced oil recovery (e.g., from oil sands and oil shale), synthetic transportation fuel and feedstock production from coal and biomass, hydrogen production supporting all the above potential applications, and metals production. Technical evaluations have been completed to show the viability of integrating the HTGR technology with conventional processes in these market sectors. Trade studies have shown the potential for integrating the HTGR technology into conventional processes for supplying steam, electricity, and high-temperature gas in co-generation applications; for production of hydrogen and for the use of it in the production of gasoline in methanol-to-gasoline processes; and production of diesel fuel in coal and biomass-to-liquid fuel conversion processes in the synthesis of ammonia.

The thermal efficiency improvements in electric power production compared with light water reactors (LWRs; e.g., 40 to $45 \%$ net efficiency for an HTGR versus 30\% for an LWR) also allow HTGRs to be constructed in areas with limited electric power transmission capacity, low cooling water availability, or other factors that would otherwise be unable to take advantage of nuclear energy. This too is potentially a very significant market for the HTGR technology.

These evaluations of the potential market and preliminary economics provide a foundation for making decisions on technical requirements for the HTGR module designs as the NGNP Project moves forward. The overall functional and performance requirements derived from these studies provide the basis for detailed design specifications to be developed by the nuclear systems suppliers in cooperation with the future HTGR plant owners. In contrast to LWRs for electric power generation, it is anticipated that as the high temperature process heat and related markets mature and the actual owners step forward to invest, a spectrum of designs will emerge that best fit each market. A primary objective of the NGNP Project is to envelop the most important of these functional and performance requirements in its supporting development work and in selecting a representative first-of-a-kind application that provides a demonstration that can be applied to broadest possible future markets.

Full realization of the NGNP Project estimate in penetrating the targeted markets for the HTGR technology over the time frame of mid-2020 to 2050 would result in:

- Deployment of 421,200 MWth (megawatts thermal) of HTGR technology (827 reactor modules rated at 600MWth) 
- Providing steam, electricity, and high-temperature gas to the process heat market, providing steam and hydrogen for bitumen recovery and upgrading from oil sands, producing hydrogen for the merchant market, and producing synthetic fuels and feedstock from coal and biomass

- Providing a significant fraction of non-greenhouse-emitting electricity generation on the national electrical grid

- Reducing the importation of $\sim 2.4$ million barrels of imported crude oil per day $(\sim 25 \%$ of the imported oil in 2009); replacing the equivalent in crude oil based gasoline and diesel fuels with synthetic transportation fuels produced from coal

- Implementing a beneficial and efficient use of coal without generating greenhouse gas emissions

- Reducing 3.3 trillion scf in natural gas consumption in the United States, per annum

- Reducing $\mathrm{CO}_{2}$ emissions of $\sim 390$ million metric tons per annum (reducing by $\sim 7 \%$ the total $\mathrm{CO}_{2}$ emissions in the United States).

A broader based study of strategies for transforming the U.S. energy infrastructure show that the HTGR technology can be an even more significant asset in improving the energy security in the United States (reduce reliance on imported oil), stabilizing energy prices (insulating the price of energy and feedstock from the large variations seen in natural gas prices over the last decade), and reducing $\mathrm{CO}_{2}$ emissions. ${ }^{1}$

Preliminary business models have been formulated and economic evaluations of these business models have been performed to establish the economic viability of these applications. These business models address the fundamental differences in the economics of a nuclear plant, which are sensitive to capital recovery, with a fossil fired plant (e.g., natural gas) whose economics are driven primarily by fuel costs. These business models also address, at a preliminary level, the potential differences in the economic criteria and financial parameters that apply to ownership of a nuclear plant versus that of a conventional industrial plant. They also provide flexibility in addressing varying scenarios of nuclear plant and industrial process ownership and operation, (e.g., a likely condition is that the nuclear plant will be operated by an entity with prior experience in operation of a nuclear plant rather than by the industrial plant owner. The industrial plant owner could own all, part, or none of the nuclear plant). These business models and the economic evaluations will evolve as the NGNP Project progresses and business cases for specific applications are developed.

Because of the preconceptual stage of design of the HTGR for these applications, there is large uncertainty in the capital and operating costs of the HTGR plant and, therefore, comparably large uncertainty in the results of the economic evaluations. However, the evaluations show that the HTGR technology can be competitive with traditional fossil fired processes, depending on the assumptions of capital and operating costs, financing, and the potential for governmental policies to put a cost on carbon emissions in the future. However, the real impact of the economic evaluations on the viability of the HTGR technology is not easily addressed generically. The end user of the technology may consider the long-term benefits of the technology such as security and stability in the price of this energy source and shelter from the potential costs of carbon emissions sufficient to justify a higher initial cost for that energy. How to account for this fact is being pursued with the end users and other stake holders in development of the HTGR technology.

To develop confidence in the technical and economic viability of the HTGR technology, the plant designs need to be progressed beyond their current preconceptual status to provide better estimates of performance and costs to construct and operate. The economic factors for financing and pricing of energy over the long operating lifetime of the HTGR plants need to be refined through further discussion with major financial institutions with an energy portfolio, current nuclear plant owners, and major industrial plant owners that can benefit from use of energy from the HTGR. 
The NGNP Project is developing updated and more refined economic models for evaluating the viability of the business models for both the HTGR plant and the industrial plant for the processes evaluated to-date and for those for which evaluations are to be completed. As the designs of the HTGR plants evolve, better estimates of the capital and operating costs for these plants will be developed supporting higher confidence levels in the results of the economic models. This will, in turn, improve the confidence in the continuing evaluations of the technical and long term economic viability of HTGR applications. 


\section{CONTENTS}

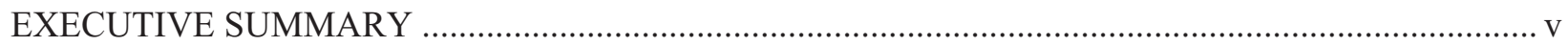

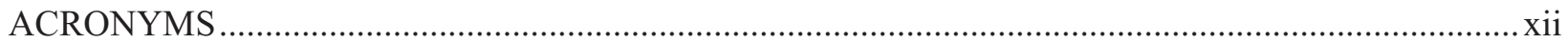

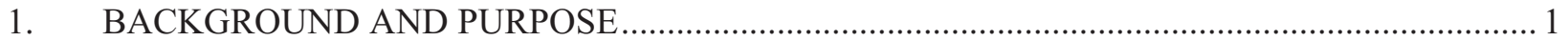

2. ASSESSMENT OF THE HTGR MARKET FOR SUPPLY OF PROCESS HEAT TO THE

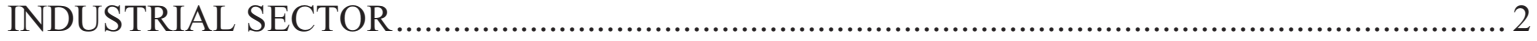

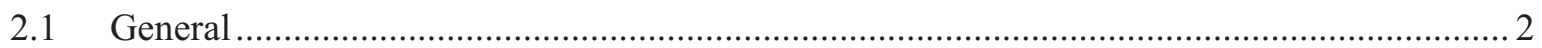

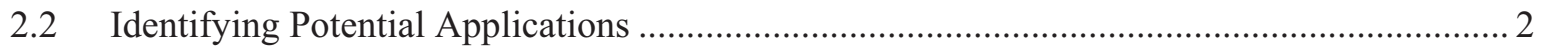

2.3 Characterizing the Potential Market................................................................................... 3

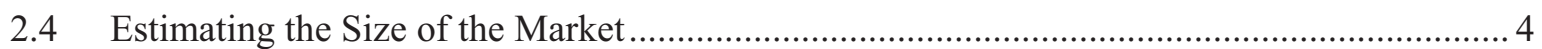

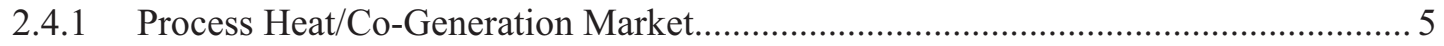

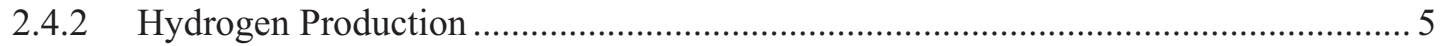

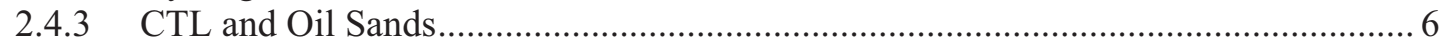

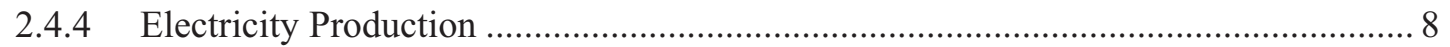

2.4.5 Summary of Deploying HTGR Technology as Described Above ............................. 9

2.5 Schedule and Benefits to Deployment of HTGR Technology ............................................. 10

2.6 Technical and Economic Evaluations of HTGR Technology Integration with

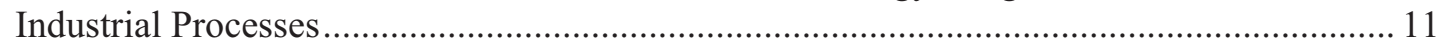

3. BUSINESS CONSIDERATIONS IN APPLYING THE HTGR TECHNOLOGY TO

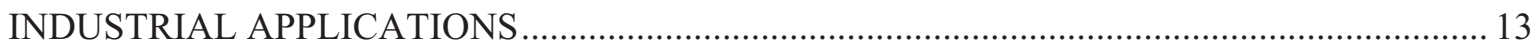

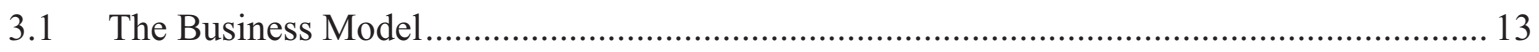

3.2 HTGR Plant Economics versus CCGT Economics ......................................................... 13

3.3 Example of Possible HTGR and Industrial Plant Business Cases ...................................... 14

4. EXAMPLES OF APPLICATION OF THE HTGR TO INDUSTRIAL PROCESSES ................... 16

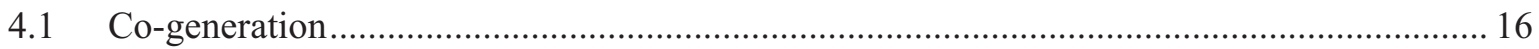

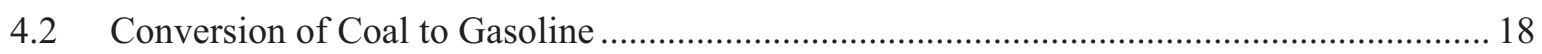

4.3 Integration of the HTGR Technology in an Ammonia Production Plant.............................. 22

4.4 Effect of Uncertainties on Economic Evaluations ............................................................. 25

4.5 Conclusion on Application Economics ............................................................................ 27

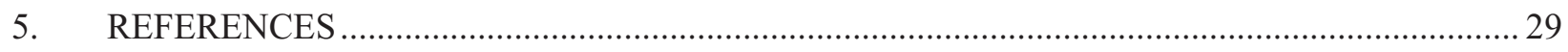

\section{FIGURES}

Figure 1. Process temperature requirements versus LWR and HTGR operating temperatures.................... 3

Figure 2. Projected penetration of the target markets. ......................................................................... 4

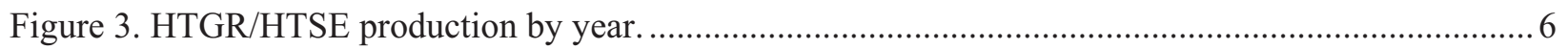

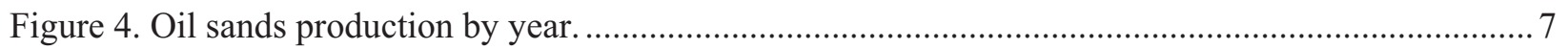

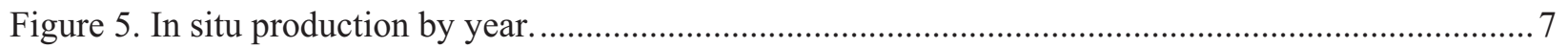


Figure 6. Comparison of life cycle emissions of HTGR based applications with conventional fossil based applications for transportation fuel production.

Figure 8. Comparison of the operating cost elements of an HTGR with a CCGT plant. .......................... 13

Figure 9. Comparing the price of steam generated by an HTGR with that generated by a CCGT

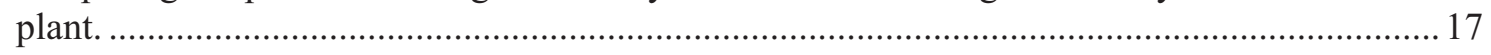

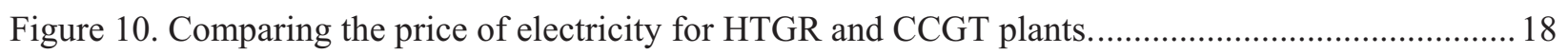

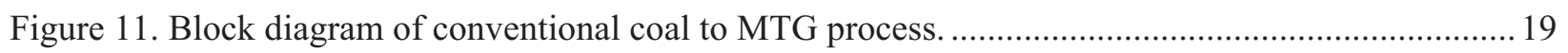

Figure 12. Block diagram of the HTGR integrated coal to MTG process.............................................. 19

Figure 13. Conventional coal-to-MTG process compared with HTGR integrated coal-to-MTG

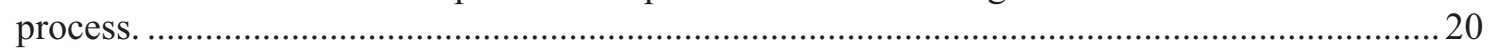

Figure 14. Results of the economic evaluation of conventional and HTGR integrated coal-toMTG plants. [Gasoline price: well to tank; Peak and Low \$/gal between 2000 and 2009].

Figure 15. Comparison of the production price of gasoline for crude oil refining, conventional coal to MTG and HTGR integrated coal to MTG processes.

Figure 16. Use of the HTGR instead of natural gas firing in the primary reforming stages..................... 23

Figure 17. Use of the HTGR for supply of hydrogen directly to the ammonia syntheses reactor.............23

Figure 18. Summary of results for use of the HTGR for ammonia production. ........................................ 24

Figure 19. Comparison of conventional and HTGR integrated plant urea pricing versus costs for

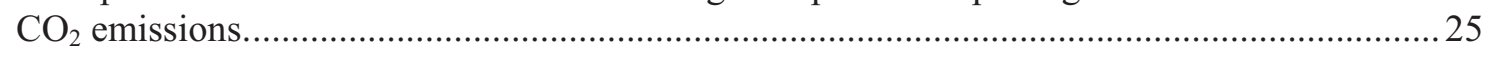

Figure 20. Effect of variations in financial parameters on hydrogen pricing. ...........................................26

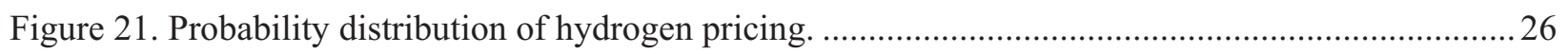

Figure 22. Comparison of hydrogen pricing using SMR and HTGR/HTSE technologies....................... 27

\section{TABLES}

Table 1. Prioritization of potential industrial applications of the HTGR technology ................................ 2

Table 2. U.S. energy consumption in 2009 by sector. ........................................................................... 3

Table 3. Summary of selected industries' energy consumption in the industrial sector............................. 4

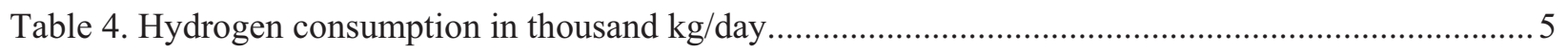

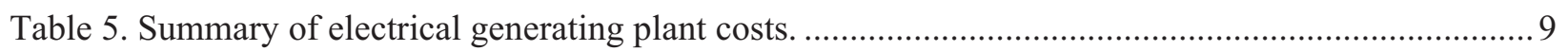

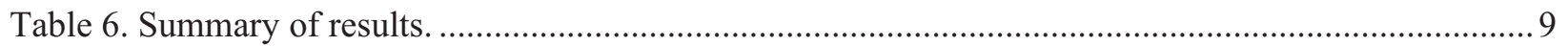




\section{ACRONYMS}

$\begin{array}{ll}\text { AEO } & \text { Annual Energy Outlook } \\ \text { CCGT } & \text { Combined Cycle Gas Turbine } \\ \text { DOE } & \text { Department of Energy } \\ \text { EIA } & \text { Energy Information Agency } \\ \text { HTGR } & \text { High-Temperature Gas-Cooled Reactor } \\ \text { HTSE } & \text { High Temperature Steam Electrolysis } \\ \text { INL } & \text { Idaho National Laboratory } \\ \text { LPG } & \text { liquid petroleum gas } \\ \text { LWR } & \text { light water reactor } \\ \text { MTG } & \text { methanol to gasoline } \\ \text { NGNP } & \text { Next Generation Nuclear Plant } \\ \text { SMR } & \text { steam methane reforming }\end{array}$




\section{High Temperature Gas-Cooled Reactor Projected Markets and Preliminary Economics}

\section{BACKGROUND AND PURPOSE}

The Next Generation Nuclear Plant (NGNP) Project was initiated at Idaho National Laboratory (INL) by the Department of Energy (DOE) as part of the Generation IV Nuclear Energy Systems technology roadmap and pursuant to the 2005 Energy Policy Act. The principal objective of the NGNP Project is to support commercialization of high temperature gas-cooled reactor (HTGR) technology. The HTGR is helium cooled with a graphite core that can operate at reactor outlet temperatures much higher than conventional light water reactor (LWR) technology. Accordingly, it can be applied in many industrial applications as a substitute for burning of fossil fuels, such as natural gas, in addition to producing electricity - the principal application of LWRs. Applications of the HTGR technology that have been evaluated by the NGNP Project for supply of process heat include supply of electricity, steam and hightemperature gas to a wide range of industrial processes, and production of hydrogen and oxygen for use in petrochemical, refining, coal-to-liquid fuels and synthetic feedstocks, chemical, and fertilizer plants.

As a non- $\mathrm{CO}_{2}$ emitting substitute for the burning of fossil fuels in industrial applications the HTGR can offset significant quantities of $\mathrm{CO}_{2}$ emissions attendant to the burning of these fuels. These emissions derive from both the direct combustion of these fuels in the industrial processes (e.g., providing steam, electricity for internal use, supplying high temperature gas) as well as the emissions associated with electrical power taken from the grid. This is one of the several benefits of the HTGR technology that have been explored by the NGNP Project with potential end users of this technology in the industrial sector. Several studies have been performed that demonstrate this benefit as well as the technical and economic viability of integrating the HTGR technology with specific applications, (e.g., co-generation of steam, electricity, and high temperature gas; coal-to-liquid transportation fuel conversion; bitumen extraction from oil sands using steam assisted gravity drainage; chemical, ammonia, and ammonia derivative production).

The use of the HTGR technology as a substitute for burning of natural gas in many of these applications and for conversion of coal to synthetic fuels and chemical process feedstock improves the security of the energy supply in the United States by reducing reliance on offshore imports, reduces the impact of the volatility in energy prices that have been experienced over the last few decades on the economics of industrial processes (e.g., wide swings in the prices of oil, natural gas, and coal), and preserves our limited nonrenewable energy resources (e.g., instead of burning natural gas, it is used in more productive and irreplaceable feedstock applications for producing a broad range of chemicals).

This paper summarizes the potential market for HTGR process heat and its environmental benefits in reducing $\mathrm{CO}_{2}$ emissions in these markets and the typical economics of projects in these applications and provides examples of the application of HTGR technology to industrial processes in typical co-generation supply of process heat and electricity, the conversion of coal to transportation fuels and chemical process feedstock, and the production of ammonia as a feedstock for the production of ammonia derivatives, including fertilizer. Finally, the effects of uncertainties in the capital costs and financial factors on the economics of the HTGR technology are demonstrated in analysis of the use of HTGR and the high temperature steam electrolysis process for the production of hydrogen. 


\section{ASSESSMENT OF THE HTGR MARKET FOR SUPPLY OF PROCESS HEAT TO THE INDUSTRIAL SECTOR}

\subsection{General}

Up to the time of this writing, the assessments of the potential markets and discussions with end users have focused on understanding the full energy needs of the targeted industries to inform the design requirements of the HTGR to meet these needs. As cited above, the targeted markets include established industries, such as co-generation, bitumen extraction from oil sands, and hydrogen production, and new markets such as the conversion of coal to synthetic fuels and feedstock whose development would be enhanced through application of the HTGR technology.

For the purposes of providing a basis for quantifying the benefits of using HTGR technology in these applications, the Project has assumed certain levels of penetration of these markets based on engineering judgment. The following sections summarize the approach applied in this market assessment and the results and conclusions of these assessments.

\subsection{Identifying Potential Applications}

NGNP Project trade studies have identified large, long-term markets that are judged viable for the HTGR technology. These studies first screened the industries to prioritize potential applications as shown in Table 1. ${ }^{2}$ The energy requirements for the low priority industries, (e.g., wood, pulp, paper, textiles, and pharmaceuticals) are judged to not match the capabilities of the HTGR or are not large enough to justify use of a nuclear heat source.

Table 1. Prioritization of potential industrial applications of the HTGR technology.

\begin{tabular}{|c|c|c|}
\hline Industry & Assessment & Priority \\
\hline Petroleum Refining & $\begin{array}{l}\text { Multiple refining processes have very high energy demands and suitable process } \\
\text { temperatures. }\end{array}$ & High \\
\hline Oil Recovery & $\begin{array}{l}\text { In situ bitumen extraction has a high energy demand, suitable process } \\
\text { temperature, and high growth expectations. }\end{array}$ & High \\
\hline $\begin{array}{l}\text { Coal and Natural Gas } \\
\text { Derivatives }\end{array}$ & $\begin{array}{l}\text { Syngas, hydrogen, and liquid fuel production from coal and natural gas has } \\
\text { suitable process temperatures and high projected growth. }\end{array}$ & High \\
\hline Petrochemicals & $\begin{array}{l}\text { Multiple petrochemical production processes have very high energy demands and } \\
\text { suitable process temperatures. }\end{array}$ & High \\
\hline $\begin{array}{l}\text { Industrial Gases } \\
\text { (Hydrogen) }\end{array}$ & $\begin{array}{l}\text { Steam methane reforming and advanced hydrogen production methods have high } \\
\text { energy demands and suitable process temperatures. }\end{array}$ & High \\
\hline $\begin{array}{l}\text { Fertilizers } \\
\text { (Ammonia, Nitrates) }\end{array}$ & Ammonia production has high energy demand and suitable process temperatures. & High \\
\hline Metals & $\begin{array}{l}\text { Direct-reduced iron (DRI) production has high energy demands, suitable process } \\
\text { temperatures and strong global growth. }\end{array}$ & High \\
\hline $\begin{array}{l}\text { Polymer Products } \\
\text { (Plastics, Fibers) }\end{array}$ & $\begin{array}{l}\text { Certain polymers have large energy demands, suitable process temperatures, and } \\
\text { strong global growth. }\end{array}$ & High \\
\hline Cement & $\begin{array}{l}\text { The current cement process temperatures are too high, but production is possible } \\
\text { at suitable temperatures with technology development. }\end{array}$ & Low \\
\hline Pharmaceuticals & $\begin{array}{l}\text { The process energy needs of the pharmaceutical industry on a per plant basis are } \\
\text { relatively low. }\end{array}$ & Low \\
\hline Paper & $\begin{array}{l}\text { The typical energy requirements for a mill is low and byproducts, having little } \\
\text { value otherwise, are burned to provide half of the steam and electricity needs of } \\
\text { paper products. }\end{array}$ & Low \\
\hline Glass & Glass production process temperatures are too high. & Low \\
\hline
\end{tabular}


Figure 1 compares the temperature capabilities of the HTGR with these energy requirements and the temperature capabilities of current LWR technologies. This figure shows the broad-based applicability of the HTGR technology in meeting the energy needs of the industrial sector, which cannot be met at the lower temperatures typical of current and advanced LWRs.

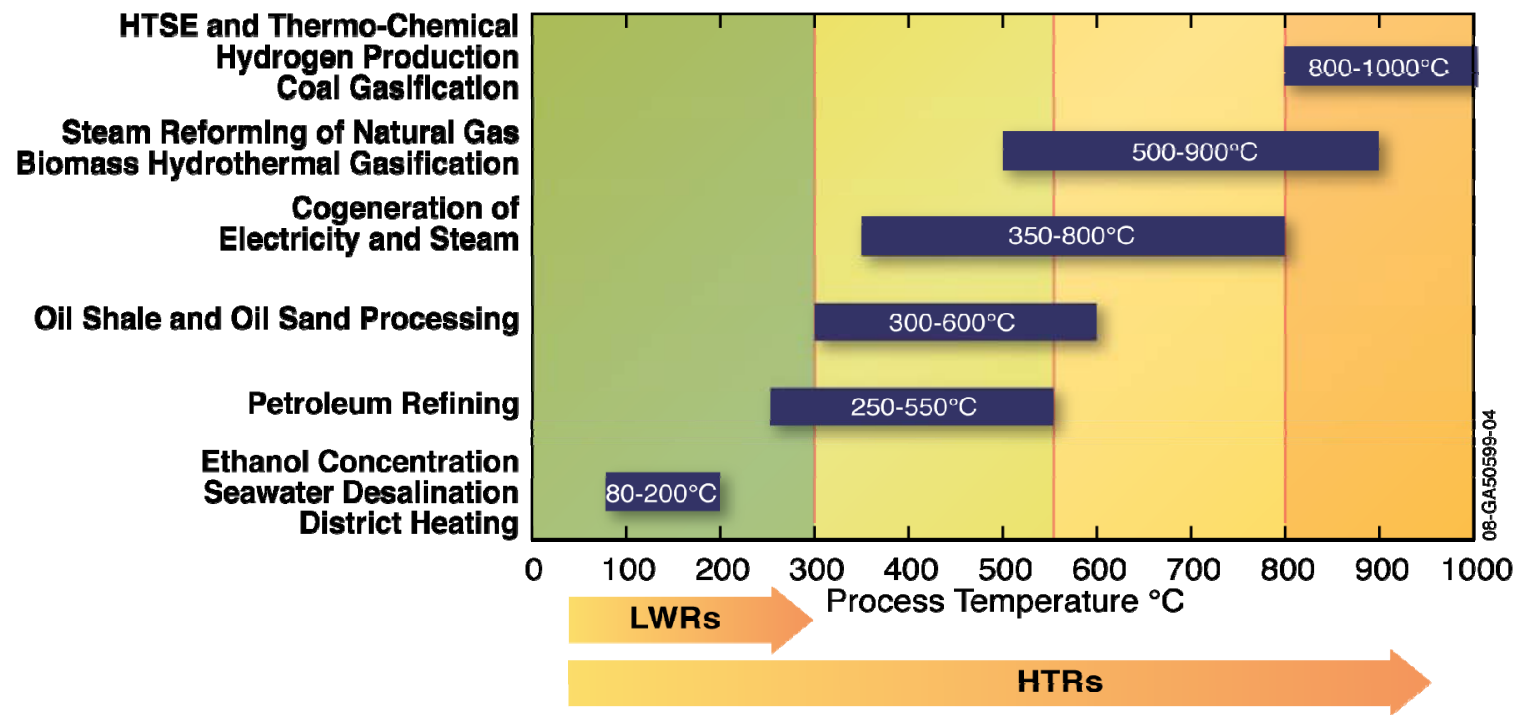

Figure 1. Process temperature requirements versus LWR and HTGR operating temperatures.

\subsection{Characterizing the Potential Market}

The NGNP Project has estimated the characteristics and magnitude of the energy needs of selected high-priority processes. The U.S. energy consumption data summarized by the DOE Energy Information Agency (EIA) in Annual Energy Outlook (AEO) reports were used for this purpose. Table 2 shows the energy consumption in the United States by sector in 2009. This data was obtained from the DOE-EIA AEO 2010 December 2009 update. ${ }^{3}$ The applications identified as high and medium priority fall within the Industrial Sector. As shown, this sector was responsible for $30 \%$ of the energy consumed in 2009. For comparison this is about 3.5 times the total energy generated by the 104 nuclear power plants in the United States in 2009 (8.49 quad Btu). The consumption of energy in 2009 by the industries that have been identified as having the highest potential for HTGR application within the Industrial Sector is summarized in Table 3. This table shows that the refining, chemical processing, iron and steel, aluminum, and plastics industries account Table 2. U.S. energy consumption in 2009 by sector. for about $40 \%$ of the total energy consumed by the Industrial Sector.

\begin{tabular}{|l|c|}
\hline \multicolumn{1}{|c|}{ Sector } & Quad Btus \\
\hline Residential & 21.49 \\
\hline Commercial & 18.32 \\
\hline Industrial & 28.8 \\
\hline Transportation & 27 \\
\hline \hline Total & 95.61 \\
\hline
\end{tabular}
Also note that about $60 \%$ of the energy consumption for the chemical industry is used for feedstock, typically natural gas. Replacement of this portion with the HTGR will be through synthetic fuel conversion such as coal to synthetic gas. Altogether, these are among the high priority applications identified in the early screening of potential applications for the HTGR technology. As shown in the last two columns of table 3, except for the Refining sector, the DOE-EIA projections through 2035 show that the Industrial Sector energy consumption is not expected to change significantly (a growth rate of $\sim 0.2 \%$ /annum is projected) over the next two decades. 
Table 3. Summary of selected industries' energy consumption in the industrial sector.

\begin{tabular}{|c|c|c|c|c|c|c|c|c|c|c|c|}
\hline \multicolumn{12}{|c|}{2009 Industrial Sector Energy Consumption (AEO 2010, December 2009) } \\
\hline Total & 28.8 & Quad & \multirow[b]{2}{*}{ Source } & \multirow[b]{2}{*}{$\begin{array}{c}\text { Electricity } \\
\text { Quads }\end{array}$} & \multirow[b]{2}{*}{$\begin{array}{c}\text { Emissions } \\
\mathrm{Mt}\end{array}$} & \multirow{2}{*}{$\begin{array}{c}\text { \% of Total } \\
\text { U.S. } \\
\text { Emissions }\end{array}$} & \multicolumn{2}{|c|}{ On-site Generation } & \multirow{2}{*}{$\begin{array}{c}\# 600 \mathrm{MWt} \\
\text { modules } \\
\text { equivalent }\end{array}$} & \multirow{2}{*}{$\begin{array}{c}\text { Projected } \\
\text { Annual } \\
\text { Change } \\
2008-2035\end{array}$} & \multirow{2}{*}{$\begin{array}{c}\text { Total } \\
\text { Quads } \\
2035\end{array}$} \\
\hline Industry & $\begin{array}{l}\text { Total, } \\
\text { Quads }\end{array}$ & $\begin{array}{c}\text { \% of Ind } \\
\text { Sector } \\
\text { Total }\end{array}$ & & & & & $\begin{array}{c}\text { Own Use } \\
\text { Elec, } \\
\text { BKWh }\end{array}$ & $\begin{array}{l}\text { Sales to } \\
\text { Grid, } \\
\text { BKWh }\end{array}$ & & & \\
\hline Refining & 3.797 & $13 \%$ & Table 34 & 0.174 & 263.2 & $4 \%$ & 15.97 & $\overline{7.4}$ & 249 & $1.2 \%$ & 5.257 \\
\hline \multirow[t]{2}{*}{ Chemical } & 5.627 & $20 \%$ & Table 37 & 0.404 & 256.7 & $4 \%$ & 43.12 & 9.23 & & $-0.3 \%$ & 5.823 \\
\hline & 2.457 & \multicolumn{7}{|c|}{ used for heat and power the rest is feedstock } & 161 & & 2.515 \\
\hline Iron \& Steel & 0.709 & $2 \%$ & Table 40 & 0.065 & 64.8 & $1 \%$ & 5.53 & 0.82 & 46 & $-1.7 \%$ & 0.842 \\
\hline Aluminum & 0.366 & $1 \%$ & Table 41 & 0.156 & 41.5 & $1 \%$ & 4.57 & 1.6 & 24 & $-0.6 \%$ & 0.299 \\
\hline Plastics & 0.269 & $1 \%$ & Table 43 & 0.155 & 36.2 & $1 \%$ & N/A & N/A & 17 & $0.5 \%$ & 0.334 \\
\hline Quad $=1 \mathrm{e} 15 \mathrm{Btu}$ & \multicolumn{6}{|c|}{$M t=$ million metric tons } & \multicolumn{5}{|c|}{ thours } \\
\hline
\end{tabular}

\subsection{Estimating the Size of the Market}

Figure 2 summarizes the projected penetration of the potential markets. The following discusses the development of this figure.

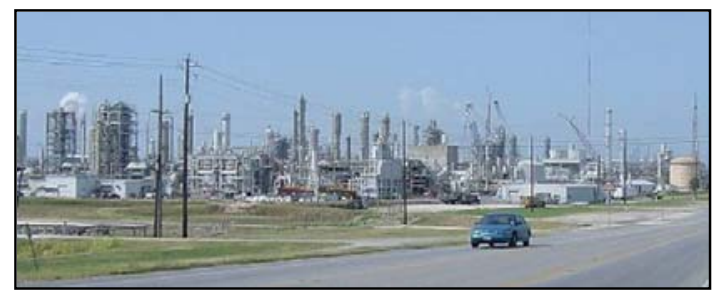

Petrochemical (35 - 600 MWt HTGR Modules)

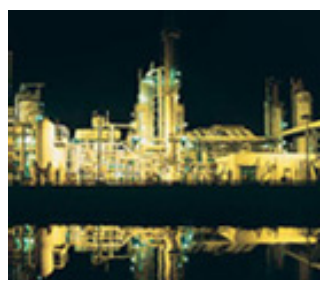

Fertilizers/Ammonia (20 - 600 MWt HTGR Modules)

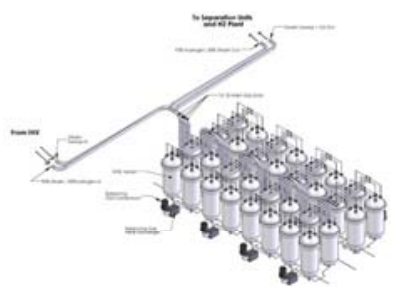

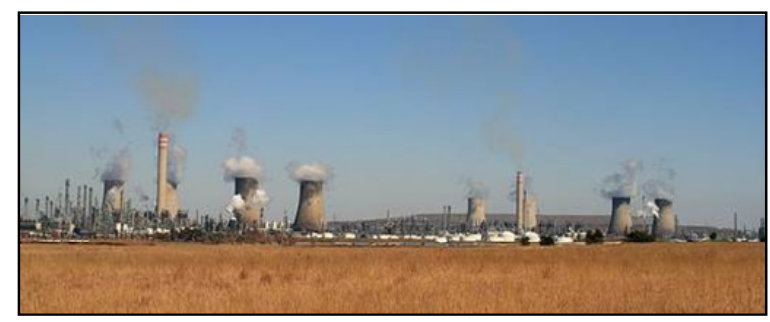

Coal-to-Liquids (415 -600 MWt HTGR Modules)

Hydrogen Production (60 - 600 MWt HTGR Modules)

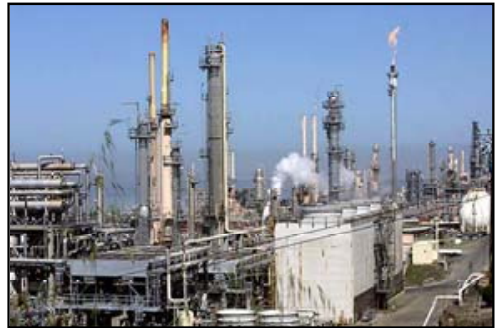

Petroleum Refining (75 - 600 MWt HTGR Modules)

Figure 2. Projected penetration of the target markets.

The following sections identify the specific industries and processes that are targeted for application of the HTGR technology and summarize NGNP Project estimates of the potential scope for deployment of the HTGR technology as the energy supply for these industries and processes. These start with the cogeneration and process heat market covering the petrochemical, refining, ammonia/fertilizer production, iron and steel, aluminum, and plastics industries followed by the hydrogen production, oil and oil shale recovery, and conversion of coal to synthetic fuels and feedstock industries. The thermal efficiency 
improvements in electric power production compared with LWR (e.g., 40 to $45 \%$ net efficiency for an HTGR versus $\sim 30 \%$ for an LWR) also allow HTGRs to be constructed in areas with limited transmission and distribution capacity, low cooling water availability or other factors that would otherwise be unable to take advantage of nuclear energy. This too is a potentially important market for the HTGR technology covered below.

\subsubsection{Process Heat/Co-Generation Market}

As shown in Table 3, if the HTGR technology were substituted for the energy consumed by these industries in 2009, 300,000 MWth of HTGR energy, (equivalent to 500 reactor modules rated at $600 \mathrm{MWth}$ ) would be required. ${ }^{\mathrm{a}}$ As noted previously, DOE-EIA projects a modest $0.2 \%$ annual growth rate in Industrial Sector energy consumption over the period 2008 to 2035. The projected consumption in 2035 by the five industries highlighted in this analysis is shown in Table 3. Because little growth in energy consumption is projected in the Industrial sector, penetration of this market with the HTGR energy supply would be as replacements of existing energy production facilities; primarily natural gas fired steam generators, gas turbines, and combined cycle gas turbines.

For analysis purposes, a $25 \%$ penetration of these industries by HTGR technology is assumed over the period 2020 through 2050 . This would require deployment of $\sim 75,000 \mathrm{MWth}$ or 125 reactor modules rated at $600 \mathrm{MWth}$. If these are distributed according to energy consumption as shown in Figure 2, it translates to 75 modules in refining, 35 in petrochemical, and 20 in ammonia and ammonia derivative production such as fertilizer. Assuming that this deployment offsets the burning of natural gas and waste gas, $\mathrm{CO}_{2}$ emissions would be reduced by $\sim 110$ million metric tons per annum (for a $90 \%$ capacity factor) and natural gas consumption would be reduced by $\sim 2.2$ trillion scf per annum ( $\sim 10 \%$ of U.S. natural gas consumption in 2009).

\subsubsection{Hydrogen Production}

The HTGR combined with high temperature steam electrolysis (HTSE) is an effective non- $\mathrm{CO}_{2}$ emitting process for producing hydrogen. Demonstration of hydrogen production was cited as an objective for development of the HTGR technology in the 2005 Energy Policy Act. ${ }^{4}$ The following list presents information about hydrogen consumption in the United States:

- The United States consumed about 9 million tons of hydrogen in 2005 (3.74 trillion scf).

- $\quad$ Table 4, provided by the National Hydrogen Association, breaks down hydrogen consumption by refineries and in the merchant market. In 2006 a little over $20 \%$ of consumption was supplied by the merchant market.

- The majority of the hydrogen consumed outside of the refining industry is produced using steam methane reforming (SMR) principally for sale (a merchant market).
Table 4. Hydrogen consumption in thousand $\mathrm{kg} /$ day.

\begin{tabular}{l|r|r|r|r|}
\multicolumn{3}{c|}{ Total } & \multicolumn{2}{|c|}{ Merchant } \\
& 2003 & 2006 & 2003 & 2006 \\
\hline Petroleum Refining & $10,960 \mid$ & 12,737 & 2,395 & 3,218 \\
\hline Chemicals Production & 9,543 & 6,501 & 647 & 692 \\
\hline Metals & 128 & 149 & 125 & 145 \\
\hline Other & 127 & 124 & 83 I & 88 \\
\hline TOTAL & 20,758 & $\mathbf{1 9 , 5 1 0}$ & $\mathbf{3 , 2 5 0}$ & $\mathbf{4 , 1 4 3}$ \\
\hline
\end{tabular}

- The refining industry uses a variety of processes and intermediate products to produce hydrogen including SMR, however, the fraction produced by SMR is not known.

a. A 600 MWth module size has been cited for convenience. Designs have been developed by the HTGR suppliers for module sizes in the range 200 to $625 \mathrm{MWth}$. The product of the number of modules and the $600 \mathrm{MWth}$ rating of each module provides the energy requirement for each industry and for the full complement of target applications in the Industrial Sector. 
- The SMR process uses natural gas as the feedstock and the heat source.

- The DOE-EIA summarized hydrogen production in the United States as follows ${ }^{5}$ :

...the refinery demand for hydrogen is increasing in order to satisfy the growing demand for hydrocarbon transportation fuels and the tightening environmental restrictions on vehicle exhaust emissions. Since 1982, there has been a 59-percent expansion of onsite refinery-owned hydrogen plant capacity - an average growth rate of about 1.2 percent per year. Prior to 2006 the United States hydrogen industry had been growing at a rate of about 7 to 10 percent per year and is projected to grow another 40 percent over the next five years. Within the refinery sector, the near-term average annual growth rate of hydrogen consumption is projected to be about 4 percent per year. The merchant share of hydrogen to refineries is estimated to grow at an annual rate of about 8 to 17 percent per year.

For the purposes of analysis it is assumed that the HTGR/HTSE process will target the merchant hydrogen production market. Although the DOE-EIA projected significant growth in the use of hydrogen in the refining industry and the United States, it will be assumed that there will be modest growth to 2020 and beyond because of the U.S. government objectives to reduce the reliance on foreign oil and expansion of the use of ethanol, hybrid vehicles, and electric vehicles in the transportation sector. A total merchant market growth rate of 5\% from 2006 will be assumed to 2020 and beyond. This would project a merchant market of $\sim 3$ million metric tons per year in 2020. If the HTGR/HTSE process was deployed at a rate such that $25 \%$ of this market was supplied by HTGR/HTSE production within the first 10 years of deployment (2020 to 2030) and then continued at that percentage of the market through 2050, 36,000 MWth of HTGR/HTSE technology ( $\sim 60$ reactor modules rated at $600 \mathrm{MW}$ th) would need to be deployed over the 2020 to 2050 time frame. Figure 3 shows the HTGR/HTSE annual production by year over this deployment period.

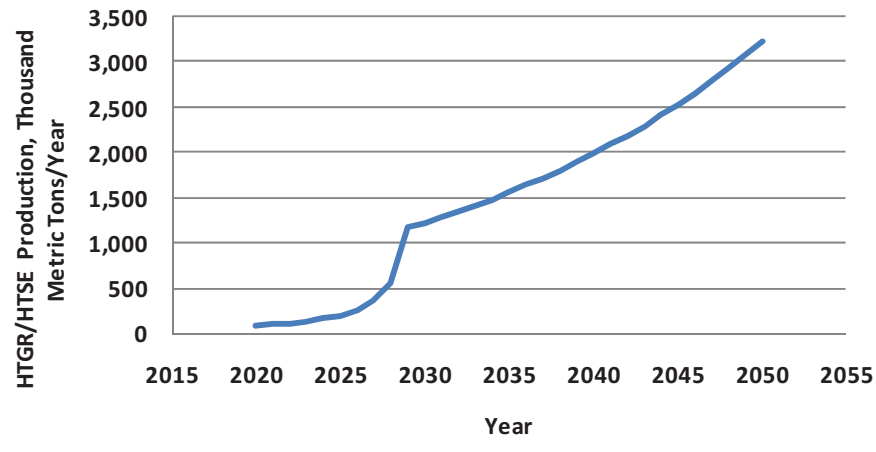

Figure 3. HTGR/HTSE production by year.

Since the SMR process consumes $\sim 2.9$ tons of natural gas and generates $\sim 4.7$ tons of $\mathrm{CO}_{2}$ for every ton of hydrogen produced, ${ }^{6}$ the application of the HTGR/HTSE process as a substitute for SMR for this annual rate of production would reduce the natural gas consumption by $\sim 10$ million tons and reduce $\mathrm{CO}_{2}$ emissions by $\sim 15$ million tons per annum in 2050. Over the 20-year period (2020 to 2050) the assumed deployment of the HTGR/HTSE technology for SMR production of hydrogen would have reduced $\mathrm{CO}_{2}$ emissions by $\sim 220$ million metric tons and natural gas consumption by $\sim 135$ million tons ( $\sim 5.9$ trillion scf)

If hydrogen were to become a major substitute for gasoline and diesel as a transportation fuel, the potential market for production of hydrogen using the HTGR would be much larger.

\subsubsection{CTL and Oil Sands}

As noted previously, there are additional applications for the HTGR technology in emerging industries. These include production of transportation fuels and feedstock from coal, natural gas, and biomass, and enhanced oil recovery from oil sands and oil shale. 


\subsubsection{Oil Sands}

The HTGR technology can be applied for steam production in support of steam assisted gravity drainage (SAGD) extraction of bitumen from the Canadian oil sands, bitumen upgrade for transport using hydrogen, and electricity production. The Canadian Association of Petroleum Producers projects an increase in oil sands production in the 2015 to 2025 time frame as shown in the Figure $4 .^{7}$ In situ (SAGD) production is expected to dominate this growth; an increase of 500,000 bpd (barrels per day) to $\sim 2,000,000$ bpd in 2025 as shown in Figure 5. If the latter rate of increase $(\sim 50,000 \mathrm{bpd}$ for years

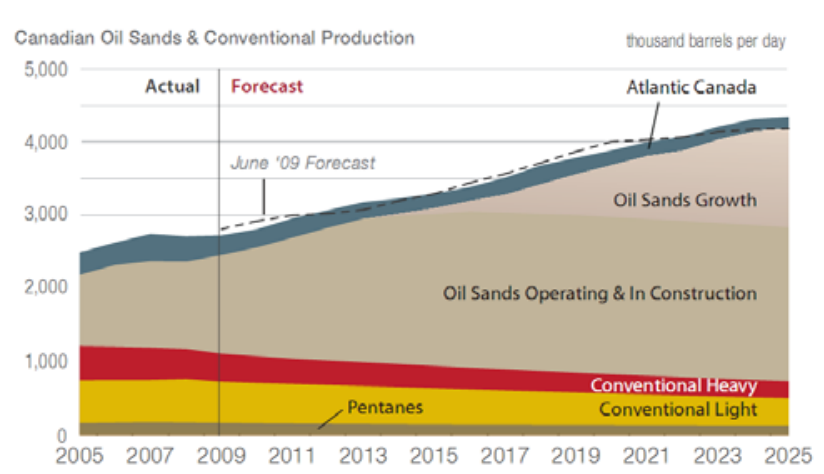

Figure 4. Oil sands production by year. 2022 to 2025) of in situ production is maintained, this process will be producing $3,250,000$ bpd by 2050 .

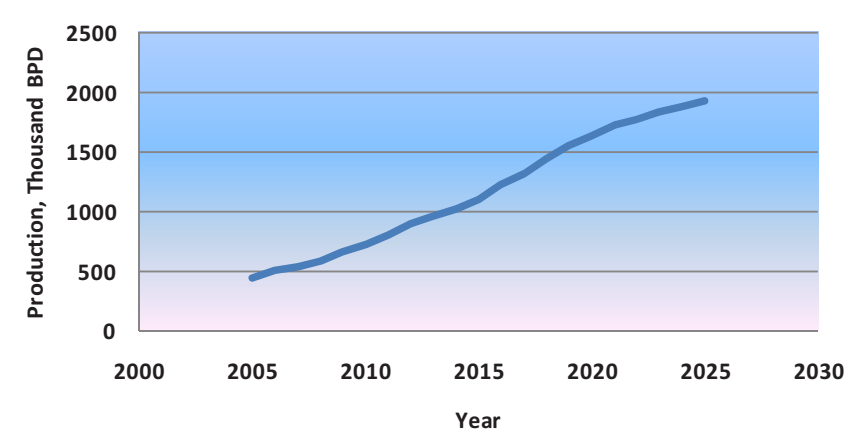

Figure 5. In situ production by year.

For the purposes of analysis it is assumed that deployment of HTGR plants will begin in 2020 and by 2030 will account for $25 \%$ of the energy required to extract and upgrade bitumen from the oil sands. This level of energy supply will be maintained through 2050 . This will result in deployment of 25,800 MWth of HTGR technology or 43 reactor modules rated at 600 MWth in this time frame for steam and hydrogen production. It is likely that additional modules could be deployed for electricity production but this has not been accounted in this analysis. By 2050 this deployment of the HTGR technology would reduce $\mathrm{CO}_{2}$ emissions by $\sim 35$ million metric tons and natural gas consumption by 650 billion scf per year.

There was no comparable estimate available for support of oil shale oil recovery at the time of this writing. This is a potential market yet to be defined.

\subsubsection{Coal to Synthetic Fuel and Feedstock Production}

If synthetic fuels and feedstock production is to make a significant contribution to improving energy security, it is assumed that it should offset at least $25 \%$ of the current U.S. imports of crude oil. Based on DOE-EIA data, the United States imported 9.12 million barrels of crude oil per day in 2009. Offsetting $25 \%$ of this would require, for example, deployment of twenty-four 100,000 bpd coal/biomass-to-liquid fuel plants, which would require $\sim 249,000$ MWth (415 reactor modules rated at $600 \mathrm{MWth}$ ) of HTGR energy to supply the energy and hydrogen required by these plants. In comparison with conventional crude oil refining, this would reduce $\mathrm{CO}_{2}$ emissions by $\sim 80$ million metric tons per annum. ${ }^{1}$ In comparison to a conventional coal to liquids plant, the use of the HTGR technology would reduce $\mathrm{CO}_{2}$ emissions by $\sim 410$ million metric tons per annum with a carbon conversion efficiency of more than $90 \%$ compared with a $\sim 35 \%$ carbon efficiency of the conventional plant. ${ }^{8}$ Figure 6 compares the life cycle emissions for conventional crude oil refining, a conventional coal-to-liquids plant, and an HTGR coalto-liquids plant. 


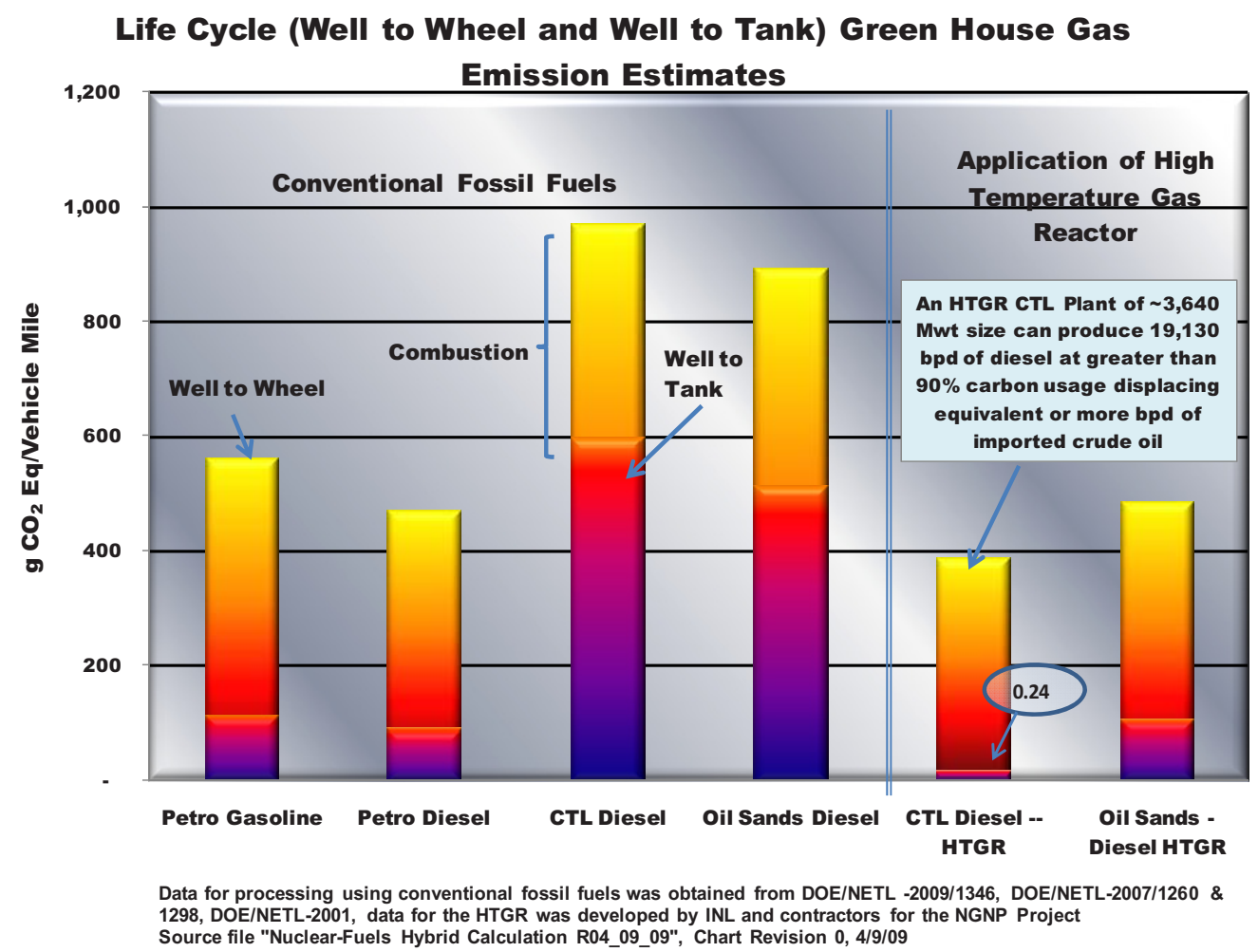

Figure 6. Comparison of life cycle emissions of HTGR based applications with conventional fossil based applications for transportation fuel production.

\subsubsection{Electricity Production}

Table 5 summarizes data from DOE-EIA, Nuclear Energy Institute, and the NGNP Pre-conceptual design work in FY 2007 on the costs of several forms of electricity production. ${ }^{9}$ As shown the HTGR is competitive with LWRs and other non-greenhouse emitting sources of electricity production. Reference 8 shows that nuclear power will need to play a significant role if the government takes actions to reduce $\mathrm{CO}_{2}$ emissions from electrical production on the national grid. An addition of up to $450 \mathrm{GWe}$ of nuclear power has been projected by 2050 in Reference 8 and in EPA assessments of the impact of pending Congressional energy legislation ${ }^{10}$ to meet government emissions reduction objectives.

A 2400 MWth HTGR plant using a Rankine steam turbine generator produces about 975 MWe. If the HTGR were assumed to account for $10 \%$ of the total nuclear power deployment on the grid in the time frame 2020-2050, forty-six 2,400 MWth plants (184 reactor modules rated at $600 \mathrm{MWth}$ ) would be required. If the HTGR plants were replacing only natural gas fired plant, the reduction in $\mathrm{CO}_{2}$ emissions in 2050 would be $\sim 150$ million metric tons per annum and natural gas consumption would be reduced by 3.4 trillion cubic feet per annum. If the HTGR plants were substituted for coal plants the reduction would be $\sim 300$ million metric tons per annum. 
Table 5. Summary of electrical generating plant costs.

\begin{tabular}{|c|c|c|c|c|c|c|c|c|c|c|}
\hline Plant & Size, Mwe & $\begin{array}{c}\text { Total } \\
\text { Overnight } \\
\text { Cost, \$2008, } \\
\$ / \text { Kwe }\end{array}$ & Cap Factor & $\mathrm{MWh} /$ annum & $\begin{array}{c}\text { Cap } \\
\text { Recovery } \\
\text { /annum, } \\
\text { \$M }\end{array}$ & $\begin{array}{c}\text { Cap } \\
\text { Recovery } \\
\text {, \$/Mwh }\end{array}$ & $\begin{array}{l}\text { Fixed } \\
\text { O\&M, } \\
\$ / M w h\end{array}$ & $\begin{array}{c}\text { Variable } \\
\text { O\&M, } \\
\$ / M w h\end{array}$ & $\begin{array}{c}\text { Fuel } \\
\text { Cost, } \\
\$ / \mathrm{Mwh}\end{array}$ & $\begin{array}{l}\text { Total } \\
\text { Prod } \\
\text { Cost, } \\
\$ / \mathrm{MWh}\end{array}$ \\
\hline Scrubbed Coal & 600 & 900 & 0.74 & $3,868,416$ & 86.64 & 22.40 & 4.27 & 4.59 & 20.41 & 51.67 \\
\hline Conv Comb Cycle & 400 & 600 & 0.42 & $1,471,680$ & 38.51 & 26.16 & 8.15 & 4.50 & 52.00 & 90.82 \\
\hline IGCC w/CCS & 380 & 3,496 & 0.74 & $2,449,997$ & 213.14 & 87.00 & 7.15 & 4.44 & 20.41 & 119.00 \\
\hline Advanced Nuclear & 1,350 & 3,318 & 0.92 & $10,856,268$ & 718.66 & 66.20 & 11.19 & 0.49 & 4.50 & 82.38 \\
\hline Wind on shore & 50 & 1,923 & 0.20 & 87,600 & 15.43 & 176.10 & 17.29 & 0.00 & 0.00 & 193.39 \\
\hline Wind off-shore & 100 & 3,851 & 0.40 & 350,400 & 61.79 & 176.33 & 25.53 & 0.00 & 0.00 & 201.86 \\
\hline HTGR (from NGNP) & 252 & 3,318 & 0.918 & $2,026,503$ & 134.15 & 66.20 & 11.19 & 0.49 & 10.00 & 87.88 \\
\hline Advanced Natural Gas & 400 & 1,245 & 0.85 & $2,978,400$ & 79.90 & 26.83 & 11.00 & 4.50 & 52.00 & 94.33 \\
\hline
\end{tabular}

\subsubsection{Summary of Deploying HTGR Technology as Described Above}

Table 6 provides a summary of the results of the assumed deployment of HTGR technology in the four sectors described above.

Table 6. Summary of results.

\begin{tabular}{|c|c|c|c|c|}
\hline Item & $\begin{array}{c}\text { Power } \\
\text { Requirement } \\
\text { (MWth) }\end{array}$ & $\begin{array}{l}\text { Number of } \\
600 \text { MWth } \\
\text { Modules }\end{array}$ & $\begin{array}{c}\mathrm{CO}_{2} \text { Emissions } \\
\text { Reductions } \\
\text { (million metric tons) }\end{array}$ & $\begin{array}{l}\text { Natural Gas Usage } \\
\text { Reductions } \\
\text { (trillion cubic feet) }\end{array}$ \\
\hline $\begin{array}{l}\text { Co-generation and } \\
\text { process heat }\end{array}$ & 75,000 & 125 & 110 & 2.2 \\
\hline Hydrogen production & 36,000 & 60 & 15 & 0.44 \\
\hline Oil sands & 25,800 & 43 & 35 & 0.65 \\
\hline $\begin{array}{l}\text { Coal/biomass to fuel } \\
\text { and feedstock }\end{array}$ & 249,000 & 415 & 80 to 410 & N/A \\
\hline Electricity generation & 110,400 & 184 & $\begin{array}{l}\sim 150 \text { replacing CCGT* or } \\
\sim 300 \text { replacing coal plant }\end{array}$ & $\begin{array}{l}3.4 \text { (if replacing } \\
150 \text { CCGT units) }\end{array}$ \\
\hline TOTALs & 421,200 & 827 & 390 to 870 & 6.69 \\
\hline
\end{tabular}

Full realization of this estimate in penetrating the targeted markets for the HTGR technology would result in:

- Deployment of 421,200 MWth of HTGR technology (827 reactor modules rated at 600 MWth)

- Providing steam, electricity, and high temperature gas to the process heat market; providing steam and hydrogen for bitumen recovery and upgrading from oil sands; producing hydrogen for the merchant market; and producing synthetic fuels and feedstock from coal and biomass

- Providing a significant fraction of non-greenhouse-emitting electricity generation on the national electrical grid

- Reducing the importation of $\sim 2.4$ million bpd of imported crude oil ( $\sim 25 \%$ of the imported oil in 2009); replacing the equivalent in crude-oil-based gasoline and diesel fuels with synthetic transportation fuels produced from coal

- Implementing a beneficial and efficient use of coal without generating greenhouse-gas emissions

- Reducing 6.69 trillion scf in natural gas consumption in the United States, per annum 
- Reducing $\mathrm{CO}_{2}$ emissions of $\sim 390$ million metric tons per annum (reducing by $\sim 7 \%$ the total $\mathrm{CO}_{2}$ emissions in the United States).

\subsection{Schedule and Benefits to Deployment of HTGR Technology}

Based on the current NGNP Project schedule the first-of-a-kind HTGR module is targeted to begin operation in the 2022 time frame. This is anticipated to be the first module in a multimodule plant supplying energy to an industrial process. It is assumed that the subsequent deployment of HTGR technology to achieve the broad range of applications targeted by the NGNP Project would occur in the mid-2020 to 2050 range. The NGNP Project has evaluated the impact of this potential deployment of the HTGR technologies in combination with other initiatives of U.S. energy infrastructure transformation to address energy security, price volatility, natural resource management, and $\mathrm{CO}_{2}$ emission reductions. ${ }^{1}$ This referenced evaluation assumed a larger deployment of the HTGR technology than is described herein, concluding that in addition to effecting a reduction in the need to import crude oil, full deployment of the HTGR technology would reduce projected annual $\mathrm{CO}_{2}$ emissions in 2050 by $\sim 915$ million metric tons. This is $\sim 16 \%$ of the total reductions in $\mathrm{CO}_{2}$ emissions in 2050 that are required to meet the emission reduction objectives of the Administration and Congress. ${ }^{10,11,12}$

In summary, there are several benefits in pursuing all of the potential applications identified for use of the HTGR technology:

- Application of the HTGR in all of the potential industrial process applications preserves our limited natural resources. Many of these processes use significant quantities of natural gas (e.g., for steam production and generation of hydrogen). The use of the HTGR technology in place of natural gas preserves this nonrenewable natural resource for more beneficial purposes.

- Application of the HTGR supports improving the energy security of the United States by reducing the need to import crude oil and natural gas.

- The use of coal and biomass as feedstock for transportation fuel production with the HTGR as the source of process heat and cogeneration supports the beneficial use of one of the most abundant forms of energy in the United States. Coal and biomass can also be converted to feedstock for petrochemical processes, thereby reducing the usage of natural gas for this purpose and improving the security of this feedstock supply.

- Changes in the long-term operating costs for production of energy from an HTGR will be affected only by traditional inflationary factors affecting personnel wages, utilities, and commodities. They will not be subject to the volatility experienced in the prices of fossil fuels over the last decade as with natural gas.

Figure 7 shows this volatility by plotting the historical and projected prices of natural gas since 1970 and projected to $2030 .{ }^{13} \mathrm{~A}$ real escalation rate of $2 \%$ per annum in natural gas prices has been observed over the last several decades. Figure 7 shows this as continuing into the future and that this escalation rate is consistent with the projections in the DOE-EIA Annual Energy Outlook 2009. (Note that the earlier projections from DOE-EIA and others are shown to illustrate how uncertain it is to project the prices of natural gas.)

Although energy pricing from the HTGR supply will be affected by market conditions the inherent stability in its operating costs will support establishing longer term stability in energy pricing to improve confidence in the long term planning of the supplied industrial processes. This not only helps to insulate these processes from energy price volatility, but also from potential disruption of sources of fossil fuels. 


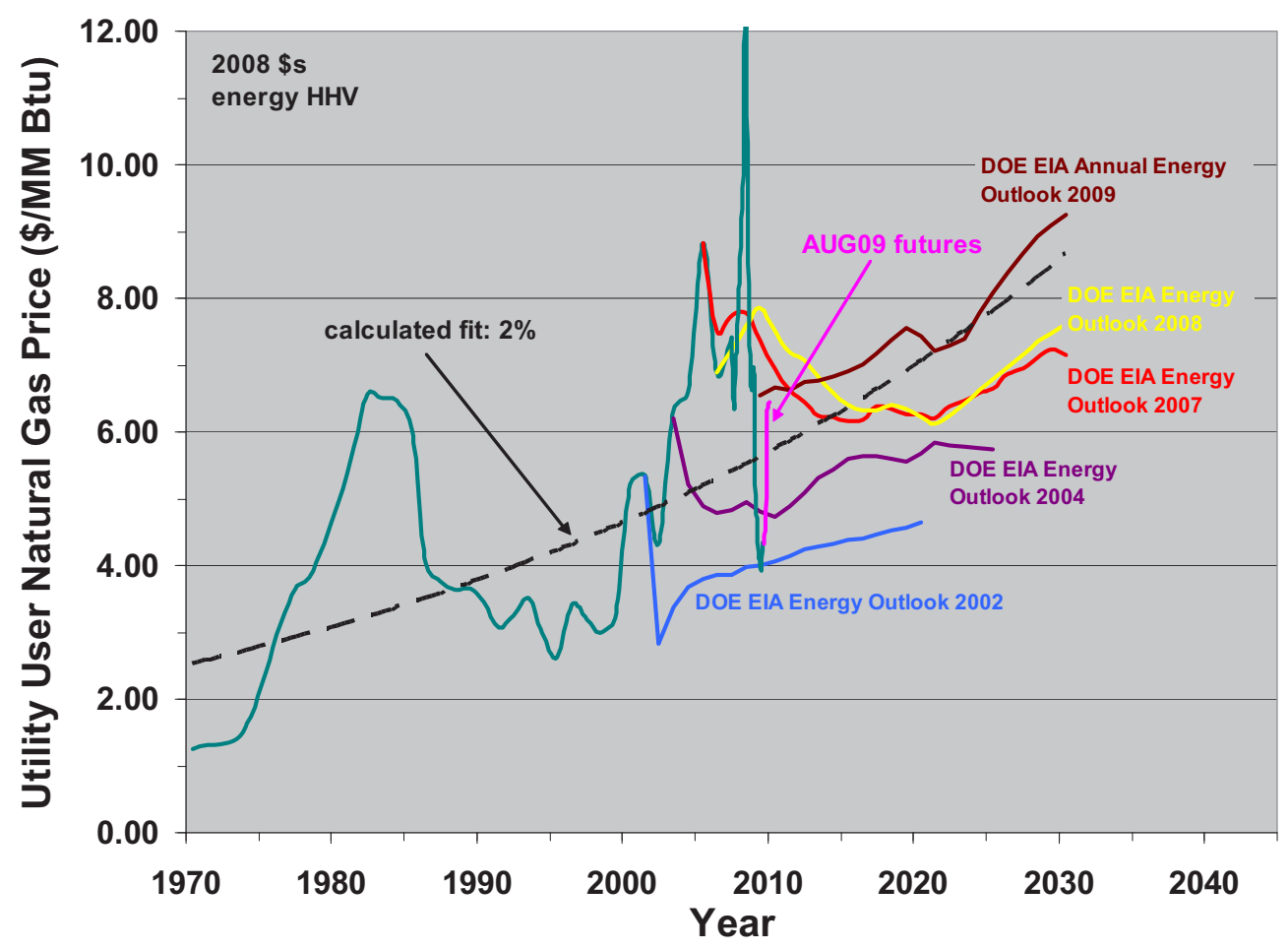

Figure 7. History and projections of utility user natural gas prices for 1970 to 2030.

Use of the HTGR technology in these applications eliminates the significant amounts of greenhouse gas emissions released by traditional processes. A comparison of the $\mathrm{CO}_{2}$ emissions of conventional processes for coal-to-liquids production and traditional crude oil refining with that supported by the HTGR technology for the production of transportation fuels is shown above in Figure 6. As can be seen, the HTGR essentially eliminates $\mathrm{CO}_{2}$ emissions from the production phase (well to tank).

\subsection{Technical and Economic Evaluations of HTGR Technology Integration with Industrial Processes}

The NGNP Project has performed technical and preliminary economic evaluations of integrating the HTGR technology with several conventional processes. ${ }^{8}$ These evaluations cover the specific processes within the applications discussed in the characterization and sizing of the potential HTGR markets above, which include:

- Using the HTGR in co-generation applications supplying steam, electricity, and hot gas as well as for electricity only production.

- Oil recovery such as recovery of bitumen from the Canadian oil sands

- Coal and natural gas derivatives such as producing ammonia from coal and natural gas, converting natural gas and coal to liquid fuels such as gasoline and diesel, and converting coal to substitute natural gas

- Petrochemicals production such as supplying steam, electricity, and hot gas to support conversion of natural gas to chemical products

- Production of hydrogen such as substituting HTGR hot gas for combustion of natural gas in the SMR process, eliminating natural gas burning and feedstock through the use of HTSE for the production of hydrogen and oxygen 
- Production of ammonia and ammonia derivatives (e.g., Urea, fertilizers) using HTGR steam and hot gas as a substitute for burning natural gas or to supply pure hydrogen and nitrogen directly to the ammonia synthesis reactor using the HTGR and HTSE

Less rigorous analyses have also been performed for the balance of the high priority items (e.g., refining and metals), and detailed evaluations will be performed in the future. At the time of this writing, five additional evaluations are ongoing:

- Shale oil recovery

- Coke/steel production

- $\quad$ SMR - temperature sensitivity study

- Biomass conversion to gas or liquids

- Methane hydrates.

The medium category processes include those that require higher temperatures than the HTGR technology can currently supply. As noted for cement production, however, it is possible that revisions to the process could reduce the temperature requirements to be compatible with HTGR temperatures and improve the efficiency of the processes. These will be explored in the future as the next set of priorities for the project or as specific potential end users in these areas are consulted. 


\section{BUSINESS CONSIDERATIONS IN APPLYING THE HTGR TECHNOLOGY TO INDUSTRIAL APPLICATIONS}

\subsection{The Business Model}

The integration of the HTGR technology with industrial processes involves the transport of energy from the modular reactors to the processes in the form of steam, electricity, high temperature gas, or other heat transport fluid (e.g., molten salt), and could include hydrogen and oxygen, depending on the process needs and the plant configuration. This is similar to current co-generation arrangements in many industrial processes wherein a central plant co-located with the process will provide energy to the process. Many of the current co-generation plants use natural gas or waste gas to generate the energy. These cogeneration plants may be owned and operated by the owner/operator of the process or by a separate entity. In the latter case, the energy is delivered under contract "over the fence." For a nuclear co-generation plant, it is judged to be unlikely that a traditional owner/operator of an industrial plant (e.g., petrochemical, refining, ammonia/fertilizer) would undertake operation of the nuclear plant, because of their lack of experience with its licensing and operating requirements. Accordingly, an entity with nuclear plant operating experience, separate from the industrial plant owner/operator, could operate the nuclear plant. The owner of the nuclear plant would enter into a contract with the industrial plant for supply of energy in the required forms "over the fence" to the processes.

\subsection{HTGR Plant Economics versus CCGT Economics}

There are fundamental differences in the economics of a nuclear plant as the energy supplier to a process compared with that of a natural gas fired combined cycle gas turbine (CCTG) plant. The latter is a common co-generation application in the industrial sector. As shown in Figure 8, in a natural gas fired plant the fuel costs account for the majority of the annual operating costs. These plants can, therefore, be cycled without major economic penalty. Much of the combined cycle plant equipment is also more "portable" than nuclear plant equipment and could be re-located if the original energy market becomes no longer available.

As shown in Figure 8, the nuclear plant costs are comparatively capital recovery intensive with low operating costs. The nuclear plant will also have a longer lifetime (e.g., 60 years) than the typical fossil based CCGT plant, (e.g., 20 to 30 years). The recovery of capital accounts for approximately $70 \%$ of the annual costs of operating a new nuclear plant compared to about $30 \%$ for a CCGT plant. Since the capital recovery is a fixed annual cost the nuclear plant must run at a high capacity factor to be economic compared to the CCGT plant. The nuclear plant also requires a long term stable energy market. This puts a premium on developing and sustaining an energy demand profile for the nuclear plant that maximizes its long term availability and capacity factor.
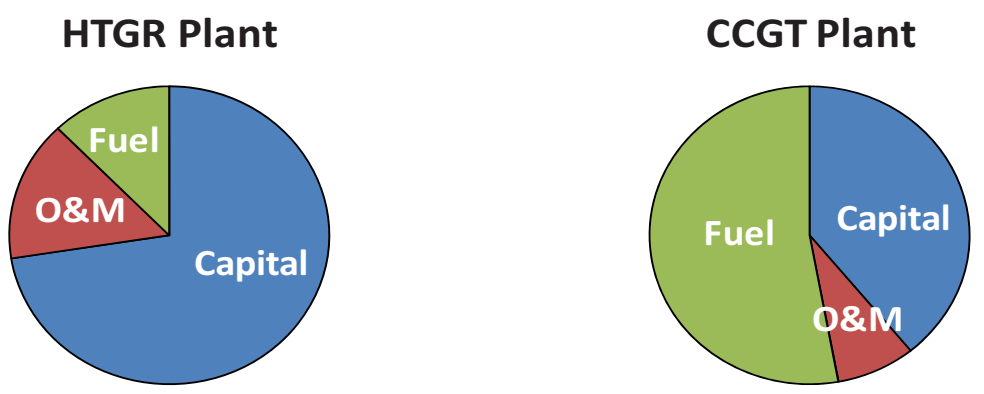

Figure 8. Comparison of the operating cost elements of an HTGR with a CCGT plant. 


\subsection{Example of Possible HTGR and Industrial Plant Business Cases}

There are two business cases that must be compatible to make integrating the HTGR technology with industrial applications economically viable: (1) that of the HTGR plant owner who will set a price for the delivered energy that fulfills his project economic criteria (typically return on the equity investment), and (2) that of the industrial plant owner who must be able to meet his economic criteria at that price of energy (e.g., setting a price for his product that is competitive and provides the requisite return and provides a hedge on feedstock real escalation and/or volatility). Evaluations of specific applications have shown that it is important to separate these two business cases because there are substantive differences in the economic factors such as debt ratio, period of financing, interest rates, and required return on investment typically applied by these two entities.

There are other factors that need to be considered in assessing the economic viability of the application.

- The HTGR plant may need to be oversized from that size required to meet the basic energy needs of the industrial process so that availability requirements for supply of the energy can be assured. Close to $100 \%$ availability requirements are typical for much of the energy supply for an industrial process. The HTGR plant owner could be expected, therefore, to assess whether there are other potential markets to which any excess energy can be offloaded. The local electrical grid is a potential taker of any excess energy. The viability of this alternative is driven by the economics of the regional electricity generation market.

- The nuclear plant owner will evaluate whether there are other industrial plants in the area or needs of the regional grid that would permit deploying an even larger plant. There are economies of scale that can benefit from siting a larger rated plant.

- The HTGR plant owner will evaluate both the regional electrical grid and other industrial plants as potential long-term alternatives for delivery of the energy if, over the longer term, the primary industrial plant is shuttered or production curtailed because of evolving economic conditions or other factors.

In a back-fit project, the owner of the industrial plant will need to assess how much, if any, of the original energy production equipment to retain in operation as backup to the HTGR plant. This may be a phased activity - less backup equipment is retained as more confidence in the reliability of the HTGR plant is developed.

For either a back-fit or Greenfield application, the owner of the industrial plant may include other factors than the price of the delivered energy in evaluating the viability of the HTGR plant as a long term energy supply. Some of these factors could include:

- The HTGR plant provides a long term (60 years or more) stable cost of energy; separating the costs of production from the significant volatility of fossil fuel prices experienced over the last decades, thus adding more certainty to future planning.

- The HTGR plant integrated with carbon conversion processes provides a long term secure and dedicated source of energy carriers and feedstock; eliminating concerns with disruption of energy carrier and feedstock supply from the traditional fossil sources.

- The HTGR plant is a non-greenhouse gas emitting source of energy, eliminating concerns with the effects of potential government policies that result in a cost for carbon emissions contributing to the volatility of the price of fossil energy.

- Fossil energy sources currently used for energy production (e.g., oil, natural gas, coal) may have more financial benefit as feedstock to the process. For example, the waste gases that were formerly burned in the power houses may be convertible to revenue producing products. When waste gas is used to provide energy to an industrial process, the differential between the cost of imported sources of the fossil fuel (e.g., natural gas) and the market price of the product that could be produced from the 
waste gas and the cost of processing the waste gas are key factors in the economics of such a conversion. In the conventional processes reviewed by the Project, these factors lead to the decision to burn the waste gas rather than process it. The factors affecting the economics of such conversion will be different with an HTGR energy source, and may be more favorable.

- For future Greenfield applications, improved efficiencies and economics are expected in the processes by reengineering them for integration with the nuclear plant.

- The schedule for initial deployment of an HTGR plant is expected to be in the mid- to late-2020s, assuming a focused and stable NGNP Project is established. While there is high uncertainty in predicting the sources, forms, and costs of energy that far into the future, the national commitment to secure the option as a hedge for such uncertainties needs to be established now. 


\section{EXAMPLES OF APPLICATION OF THE HTGR TO INDUSTRIAL PROCESSES}

The following sections discuss the results of NGNP Project evaluations of the application of the HTGR technology to supplying all or some of the energy needs of industrial processes. The firstco-generation - is judged by the Project and the HTGR suppliers to have low technical risk, a large potential market, significant energy price stability, energy security and environmental benefits, and economic viability. This judgment is based on the nature of the energy needs of this application; principally steam, electricity, and hot gas with modest temperature requirements, (e.g., 700 to $800^{\circ} \mathrm{C}$ ).

The latter two processes (conversion of coal to transportation fuels and ammonia and ammonia derivative production), which are discussed below, represent applications of the HTGR technology that address principally energy security by providing alternatives to imported crude oil and natural gas as feedstocks. These are more developmental than co-generation, relying, in some cases, on the development of the HTSE process for hydrogen production and higher HTGR operating temperatures to optimize the performance of that process. The economic evaluations of these two applications are, therefore, more uncertain. In any event, they are judged to be applications that require continued development to ensure that the benefits of HTGR technology in securing our energy sources, stabilizing our energy costs, preserving our natural resources, and reducing $\mathrm{CO}_{2}$ emissions are fully realized. The NGNP Project has received support for this continued development in discussions with major companies involved in these applications.

The economic evaluations discussed below assume engineering, procurement and construction (EPC) cost for a mature HTGR plant of $\$ 1,700 / \mathrm{kWth}$ (kilowatt thermal). This cost assumption is a nominal value based on assessment of the data generated in studies performed in the NGNP Project up to the time of this writing. Because the Project is still in the preconceptual design phase, there is large uncertainty in this cost. The Project is progressing into the conceptual design phase wherein more certain estimates of capital costs for the mature plant will be developed.

\subsection{Co-generation}

This application involves the supply of energy to an industrial process typically in the form of steam, electricity, and/or hot gas from a power plant located either outside the industrial facility or embedded in the facility. The power plant may be owned and operated by an entity separate from the owner/operator of the industrial facility or be a part of the facility itself. A large number of these power plants in the United States are fired using natural gas or coal and waste gas from the industrial processes. These plants typically include some combination of steam boilers, steam turbine generators, and CCGT plants. In a back fit application, the HTGR would replace or augment the installed equipment. In a Greenfield application, the HTGR would be the principal energy supply. As noted in previous sections, it is likely that the HTGR plant would not be operated by the owner of the industrial plant, but rather by an entity with nuclear plant operating experience such as a current nuclear power plant owner/operator. The NGNP Project and the HTGR suppliers have worked with several owner/operators of industrial plants and with an owner/operator of nuclear electrical power plants to develop business cases for this co-generation application. 
Figures 9 and 10 show a typical comparison of the prices of electricity and steam from a new HTGR plant with that of a new contemporary design natural gas fired combined cycle gas turbine plant (CCGT). ${ }^{\text {b }}$ The HTGR plant is sized at $\sim 600$ MWth - the rating required to supply a modest sized industrial plant with steam and electricity. It is compared with a CCGT with a rating of $830 \mathrm{MWth}$ for which data was available. The comparison is made for varying costs of natural gas in \$/MMBtu. This variation with natural gas price is shown because, as noted previously, the fuel costs dominate the costs of operating a natural gas fired plant. Two curves are shown for the CCGT: one for no cost for carbon emissions, the other for a cost of $\$ 50 /$ metric ton of $\mathrm{CO}_{2}$ emissions. For a natural gas fired plant, a $\$ 10 /$ metric ton cost for $\mathrm{CO}_{2}$ emissions is equivalent to $\sim \$ 0.50$ increase in the price of natural gas.

As shown in Figures 9 and 10, with no cost of carbon, the price for the HTGR plant electricity and steam is equivalent to that of the CCGT plant at natural gas prices in the range $\$ 7$ to $\$ 8 / \mathrm{MMBtu}$. For the example of $\$ 50 / \mathrm{MT}$ of carbon dioxide emissions the range would be $\$ 3$ to $\$ 4 / \mathrm{MMBtu}$. As shown in Figure 7 , over the last 5 years, natural gas prices have ranged from a low of $\sim \$ 4 / \mathrm{MMBtu}$ to a high of $\sim$ 13/MMBtu with high volatility.

The HTGR will also reduce the use of natural gas burning for this purpose, thereby preserving this limited natural resource for more beneficial uses. A base loaded 600 MWth CCGT would burn $\sim 17$ billion cubic feet of natural gas ( $\sim 800$ million $\mathrm{lb})$ per year. The HTGR also eliminates the $\mathrm{CO}_{2}$ emissions that result from the burning of natural gas. A single 600 MWth HTGR plant substituting for a base loaded CCGT reduces $\mathrm{CO}_{2}$ emissions by $\sim 800,000$ metric tons annually.

\section{Comparing Price of Steam Generated by an HTGR and a CCGT versus Price of Natural Gas and Cost of GHG Emissions}

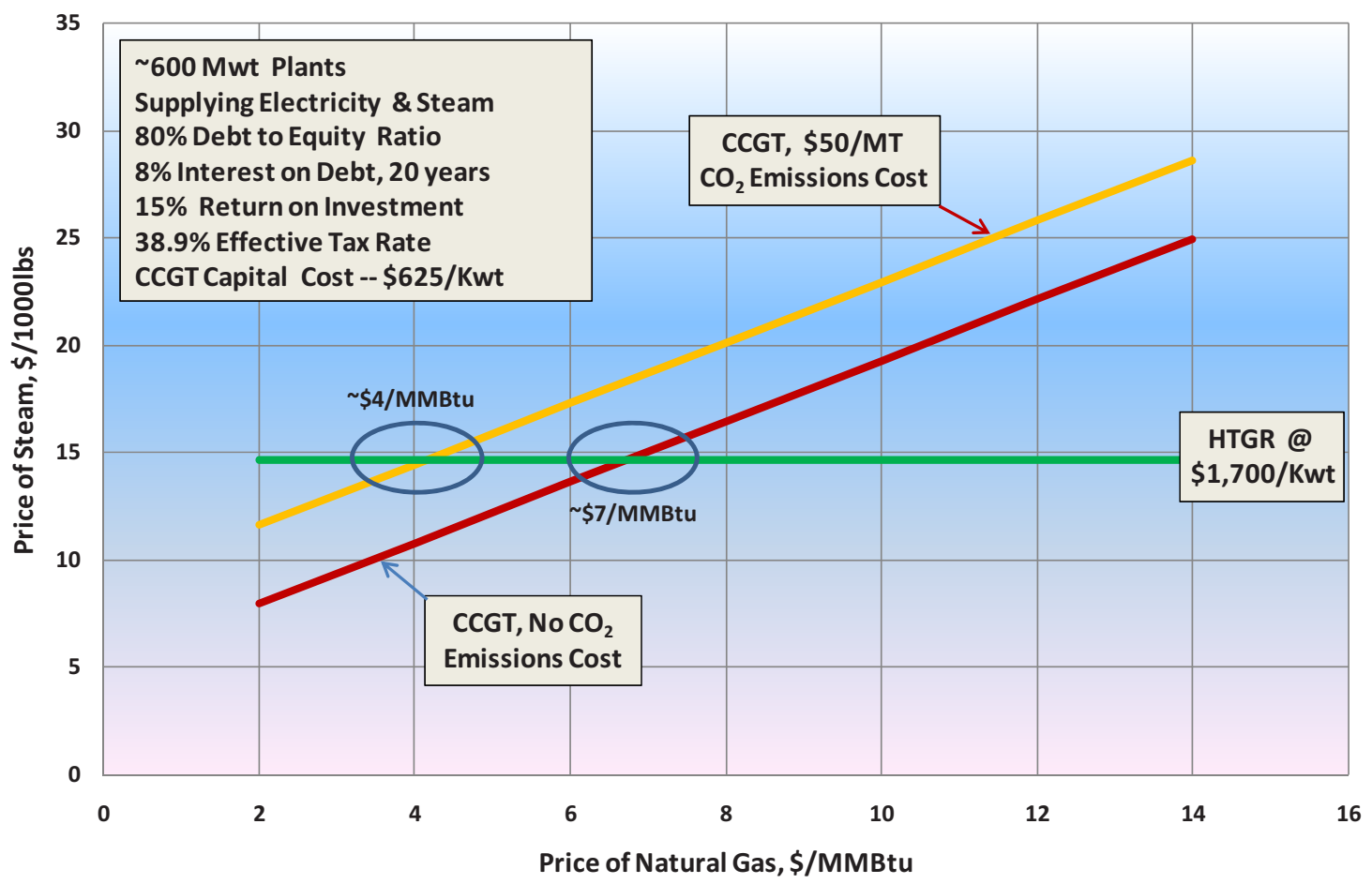

Figure 9. Comparing the price of steam generated by an HTGR with that generated by a CCGT plant.

b. The majority of evaluations performed to-date have been for energy supplies that rely on natural gas or waste gas combustion; thus the comparison with a natural gas plant. Analyses are being initiated to provide an alternative technical approach and to evaluate the economics for an energy supply system that uses coal as the fuel. 


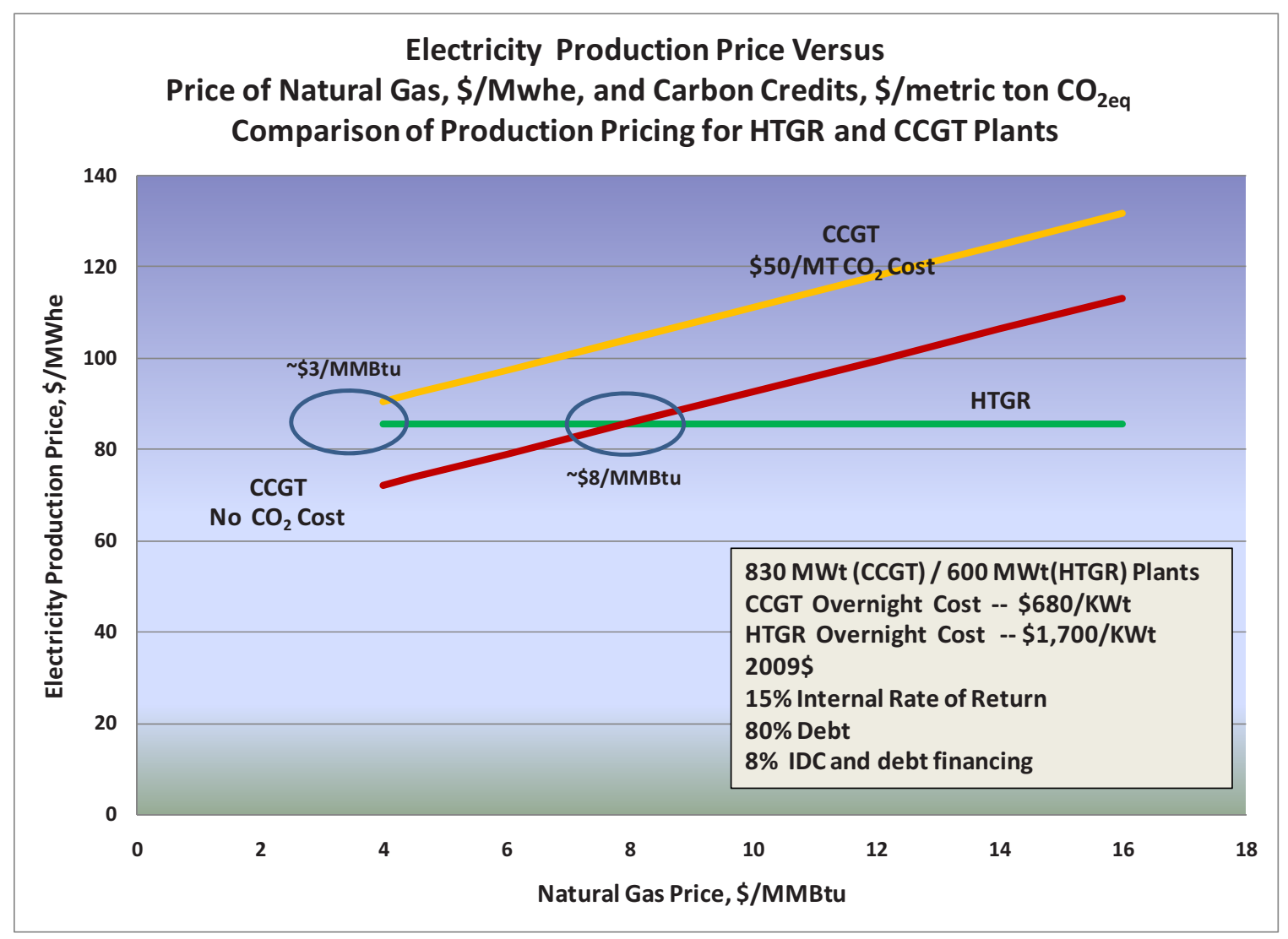

Figure 10. Comparing the price of electricity for HTGR and CCGT plants.

\subsection{Conversion of Coal to Gasoline}

One of the processes evaluated by the NGNP Project in the HTGR Integration with Industrial Process $\mathrm{Task}^{8}$ is the conversion of coal to gasoline using the methanol to gasoline (MTG) process. Liquid petroleum gas (LPG) is also produced in this process. In each of these evaluations of the potential for integration of the HTGR in the process, the conventional process is first modeled to determine where the HTGR could be used and to define the specific requirements for the HTGR application (e.g., heat input, electricity generation, hydrogen production). The conventional MTG process modeled for this evaluation is shown schematically in Figure 11.

Figure 12 shows the process with an HTGR energy source. The proposed process includes the same unit operations as the conventional coal-to-MTG process with the following exceptions: the cryogenic air separation unit and water gas shift reactors (a part of the gasification and syngas conditioning block) are replaced by HTSE to provide oxygen and hydrogen for the process.

Figure 13 summarizes the results of the evaluation. In both cases $\sim 67,000 \mathrm{bpd}$ of gasoline and LPG are produced. As shown in this figure, the use of the HTGR energy source to supply heat and hydrogen reduces $\mathrm{CO}_{2}$ emissions from the conventional process by a net amount of 100 to 31,000 tons per day $(0.04$ to 10 million tons per year) depending on the amount of $\mathrm{CO}_{2}$ that can be captured in the conventional process. 


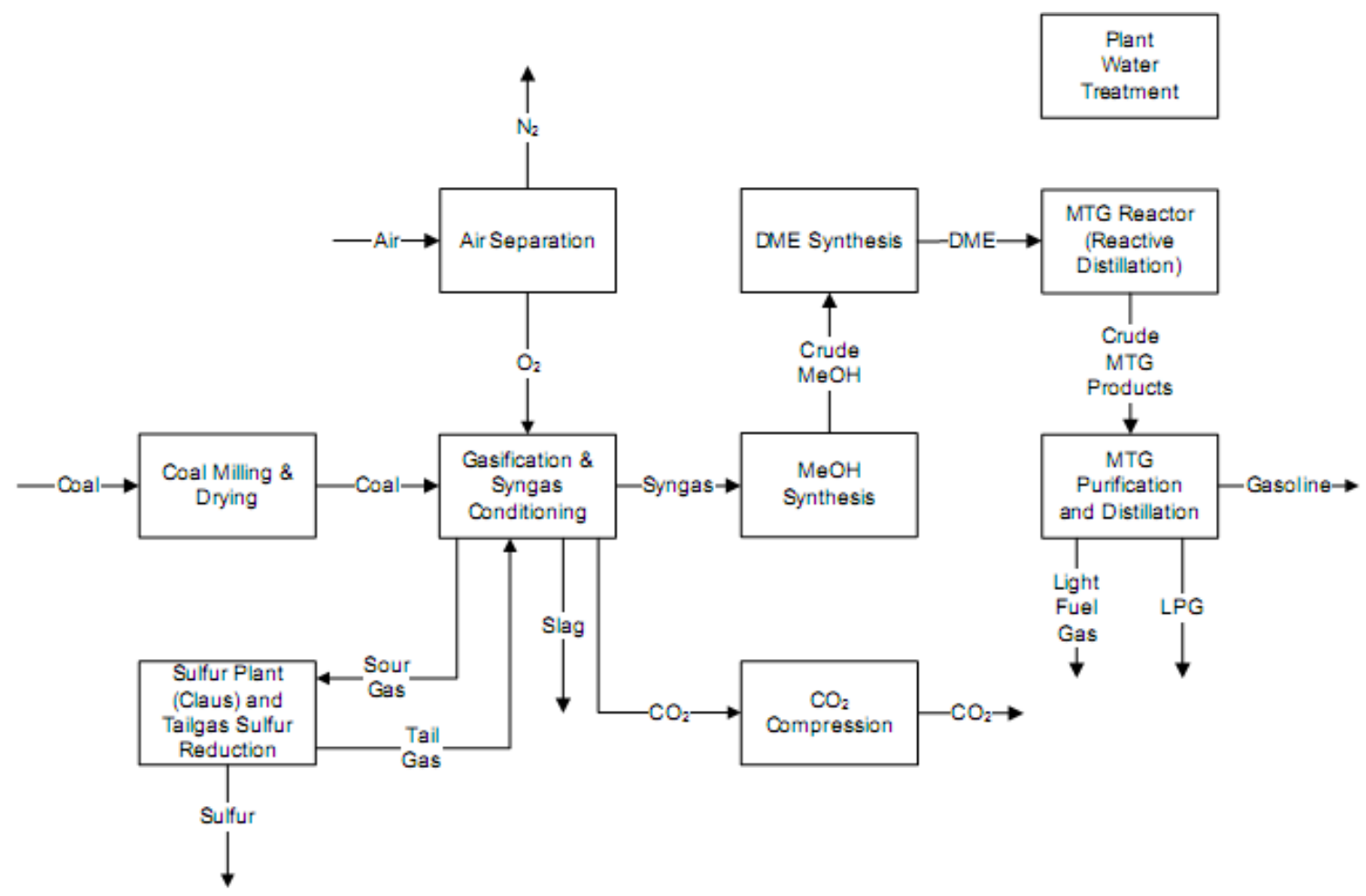

Figure 11. Block diagram of conventional coal to MTG process.

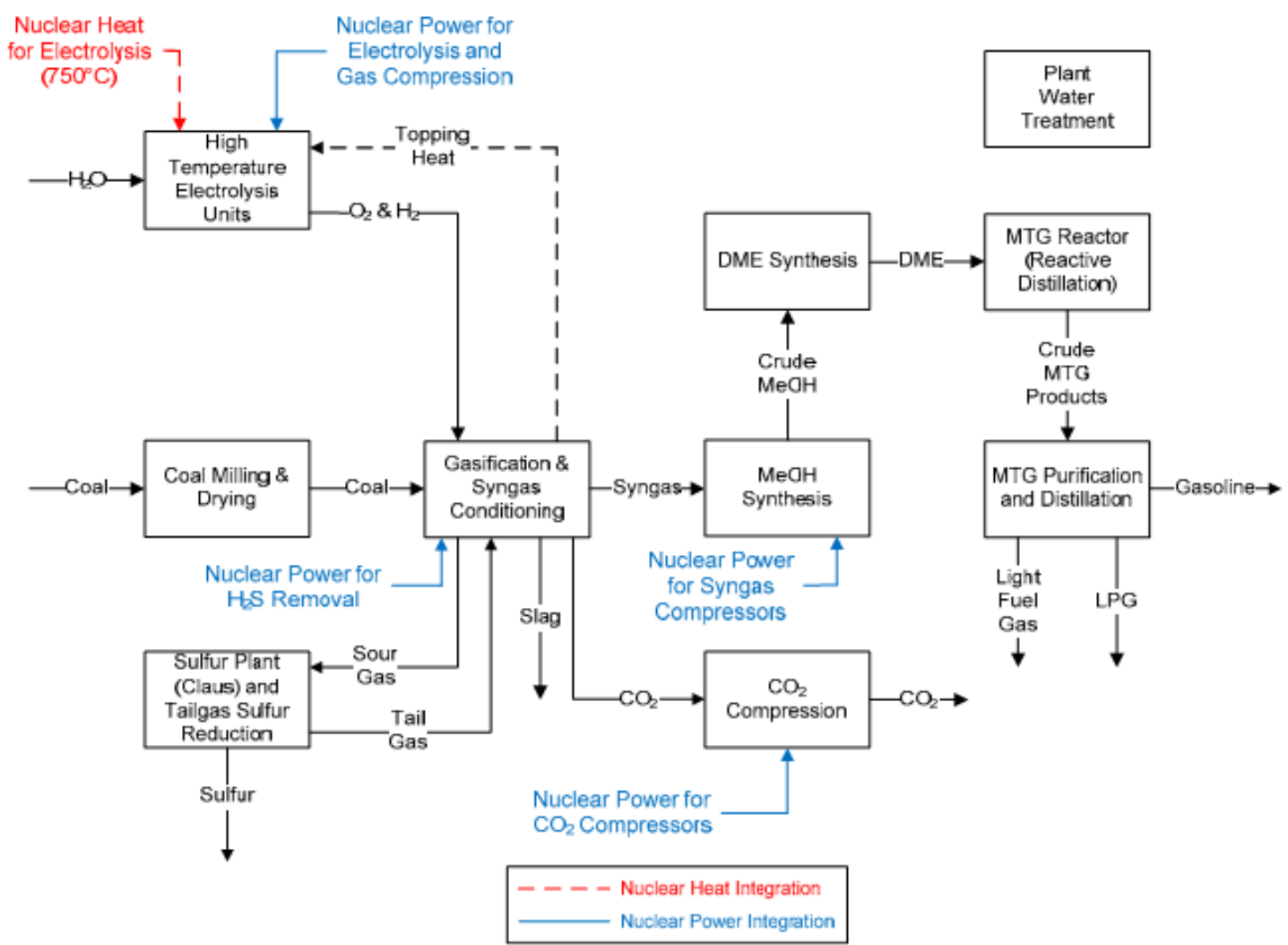

Figure 12. Block diagram of the HTGR integrated coal to MTG process. 

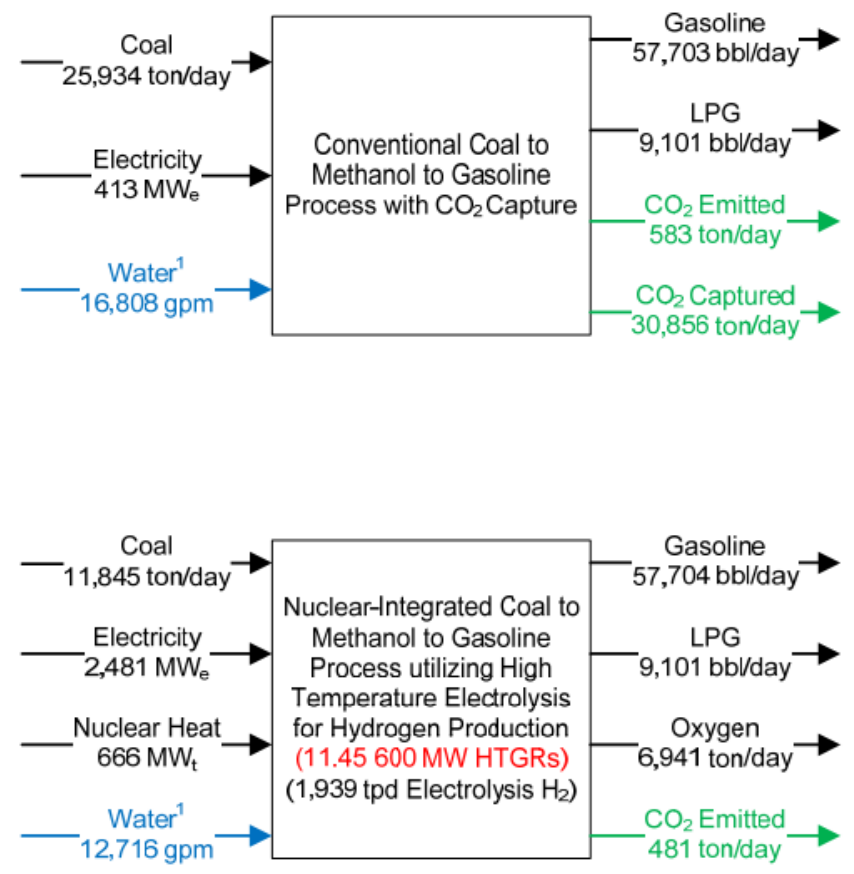

Figure 13. Conventional coal-to-MTG process compared with HTGR integrated coal-to-MTG process.

Figure 14 summarizes the economic evaluation of this HTGR application. This figure shows the production price of gasoline for the conventional and HTGR integrated processes required to meet the economic criteria summarized on the figure as a function of the cost of $\mathrm{CO}_{2}$ emissions. As shown, the HTGR plant is competitive with the conventional process for costs of $\mathrm{CO}_{2}$ emissions in the $\$ 75 /$ ton range. The historical range in the price of gasoline in 2008 is also shown on this figure for information. Use of the coal-to-MTG process for production of gasoline using either the conventional or HTGR integration approach falls within the upper end of this range.

Figure 15 shows the gasoline pricing for the conventional and HTGR integrated process and for crude oil refining as a function of crude oil price in $\$ / \mathrm{bbl}$. The price of crude oil has varied considerably over the last decade ( $\sim 25 / \mathrm{bbl}$ in January $2000, \sim \$ 130 / \mathrm{bbl}$ in July 2008$)$. As shown, the conventional coal to MTG process is competitive with crude oil refining at crude oil prices in the range of $\$ 80 / \mathrm{bbl}$ (note this is the price range of crude oil at the time of this writing) with no cost associated with $\mathrm{CO}_{2}$ emissions. At a cost of $\$ 50 /$ metric ton of $\mathrm{CO}_{2}$ emissions, the price of crude oil would have to be in the $\$ 110 / \mathrm{bbl}$ range for the conventional coal to MTG process to be competitive with crude oil refining. Similarly, the HTGR integrated process would be competitive with crude oil refining in the $\$ 125 / \mathrm{bbl}$ range.

These results indicate that the application of the HTGR technology to coal-to-MTG production of gasoline is marginally economic for the reference financial and economic factors, even when compared with the conventional process, when subjected to additional costs for $\mathrm{CO}_{2}$ emissions. The large capital cost investment required for the HTGR plant in production of hydrogen, oxygen, and process heat provides a disadvantage when compared with the relative low capital cost for the conventional plant. Additionally, the supply of hydrogen, oxygen and process heat in this case does not significantly reduce the complexity of the MTG plant and eliminate significant components and systems. Therefore, the additional costs of the HTGR plant add to rather than substitute for the majority of the conventional plant costs. The viability of this alternative would also be affected by governmental actions that prescribe the pursuit of substitute transportation fuels. 


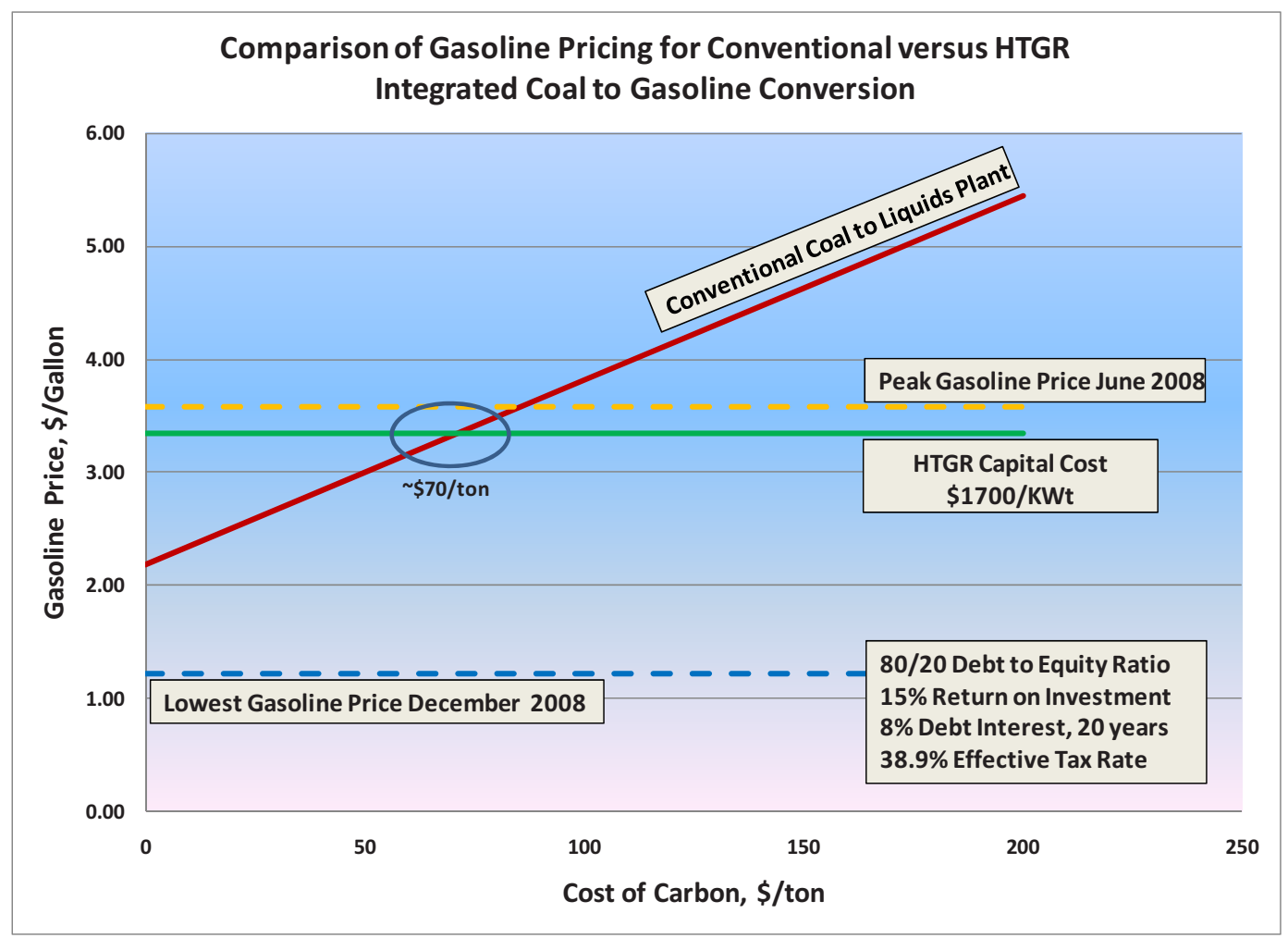

Figure 14. Results of the economic evaluation of conventional and HTGR integrated coal-to-MTG plants.

[Gasoline price: well to tank; Peak and Low \$/gal between 2000 and 2009]

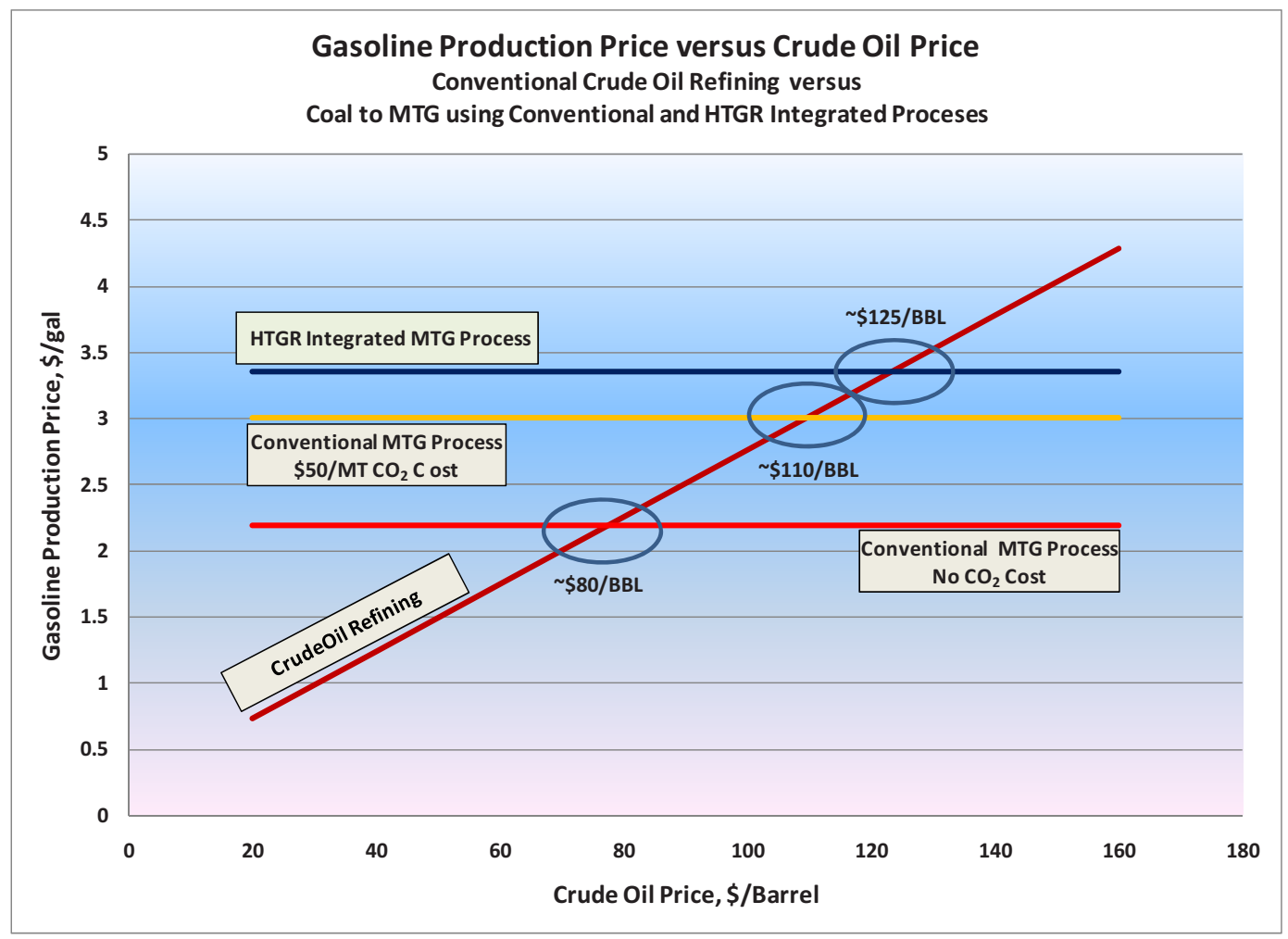

Figure 15. Comparison of the production price of gasoline for crude oil refining, conventional coal to MTG and HTGR integrated coal to MTG processes. 
As the HTGR technology develops the technical and economic viability of the technology for this application will be revisited and continued to be evaluated with potential end users.

\subsection{Integration of the HTGR Technology in an Ammonia Production Plant}

The NGNP Project has developed detailed process flow sheets for integration of HTGR process heat into processes for production of ammonia and ammonia derivative products such as urea used in the production of fertilizer. These flow sheets were validated by ammonia equipment and system designers, meetings with producers of ammonia, and a tour of an operating plant. Scoping evaluations were also initiated with the objective of comparing the economics of the HTGR integrated plant with the economics of a conventional plant. These analyses were performed for a typical plant producing 2,500 tons per day of ammonia.

In discussions about using the HTGR as a source of process heat and reviews of evaluations of integrated processes, a major producer of ammonia and ammonia derivatives recommended that the evaluations focus on just the production of ammonia. The information from that evaluation will facilitate the industry's evaluation of the viability of the output of that process for use of the ammonia as feedstock for further processing. To that end, two different applications of an HTGR integrated plant for the production of ammonia were evaluated. The first used HTGR process heat to offset the burning of natural gas in the primary reforming stages of a conventional process. A simplified flow sheet for this process is shown in Figure 16.

In the second case, the HTGR plant produces high purity hydrogen and oxygen using the HTSE process. The high purity hydrogen is delivered directly to the ammonia synthesis reactor along with nitrogen produced from a cryogenic air separation unit powered by HTGR generated electricity. A simplified flow sheet for this process is shown in Figure 17. This latter use of the HTGR plant eliminates all of the reforming and purification equipment required to supply the hydrogen from decomposition of natural gas in a conventional process. This reduces the capital investment and operating costs of the ammonia plant, making the use of hydrogen and nitrogen directly for ammonia synthesis potentially more economically attractive.

Both of these uses of the HTGR energy source result in significant reductions in $\mathrm{CO}_{2}$ emissions compared with the conventional process. Figure 18 summarizes the outputs for the two HTGR cases with the conventional plant. Depending on the case, the emissions that would be emitted from a conventional process are reduced by $22 \%$ (Case 1, 1,000 tons of $\mathrm{CO}_{2}$ emissions per day) to $98 \%$ (Case 2, 3850 tons of $\mathrm{CO}_{2}$ emissions per day). 


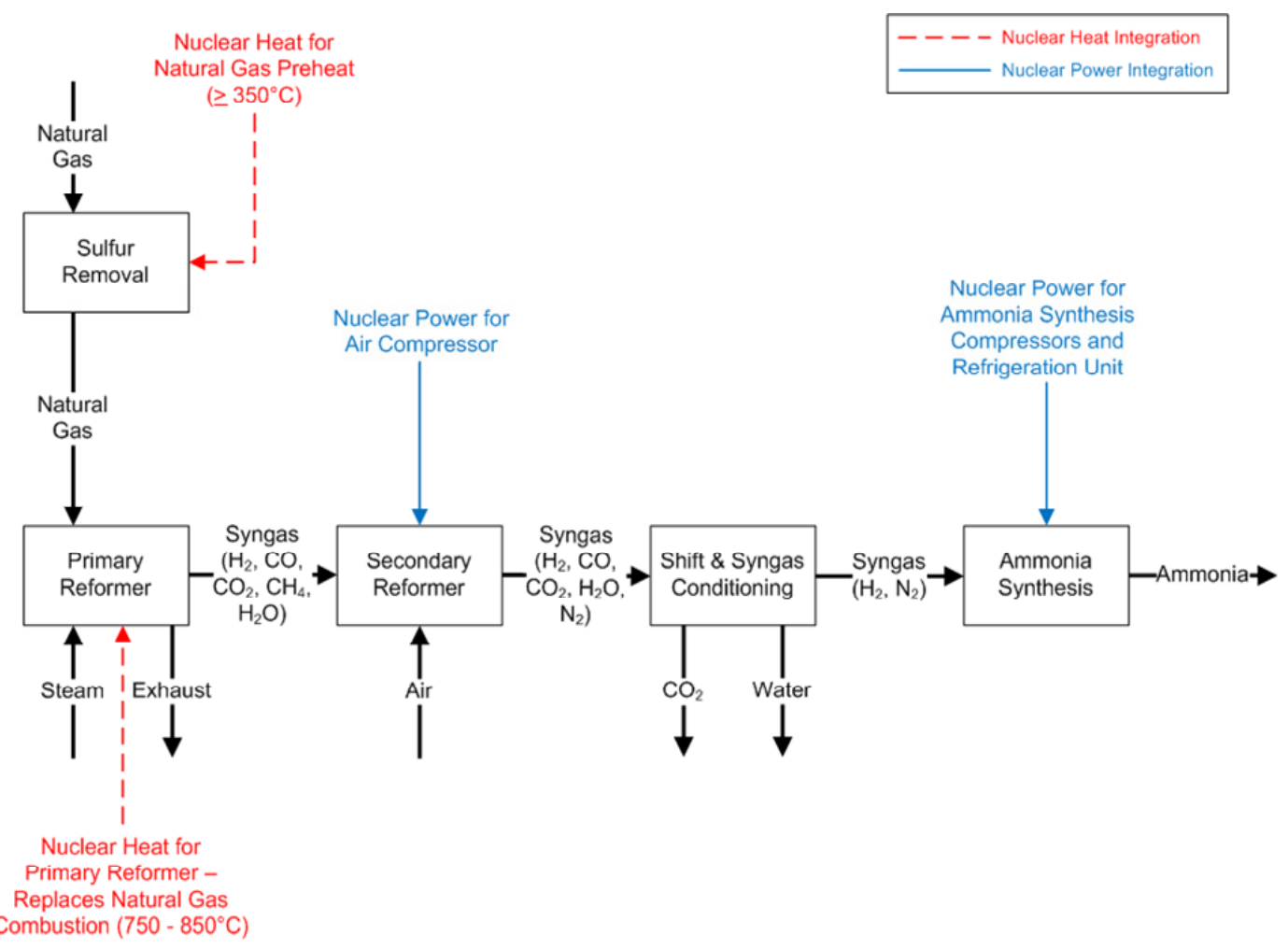

Figure 16. Use of the HTGR instead of natural gas firing in the primary reforming stages.
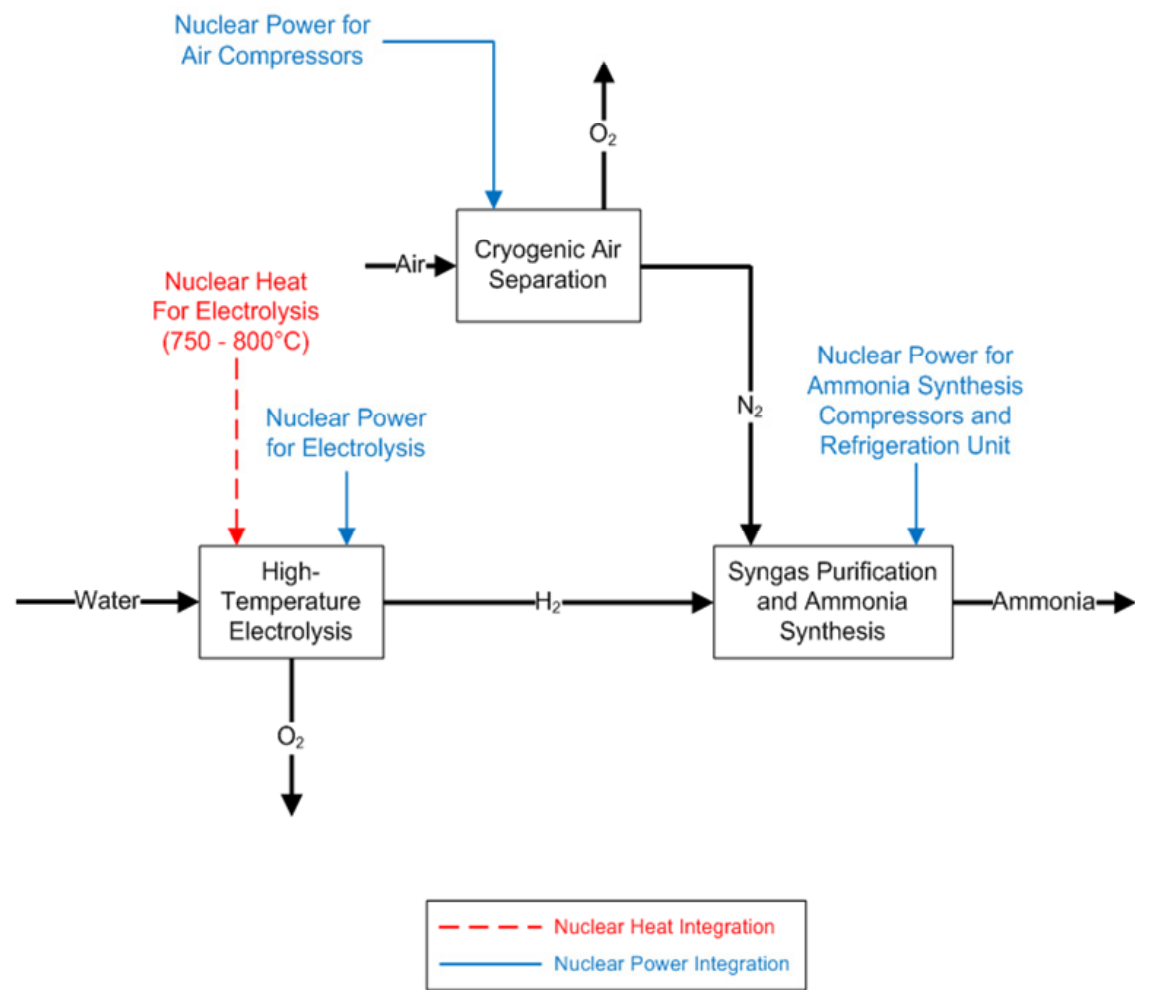

Figure 17. Use of the HTGR for supply of hydrogen directly to the ammonia syntheses reactor. 

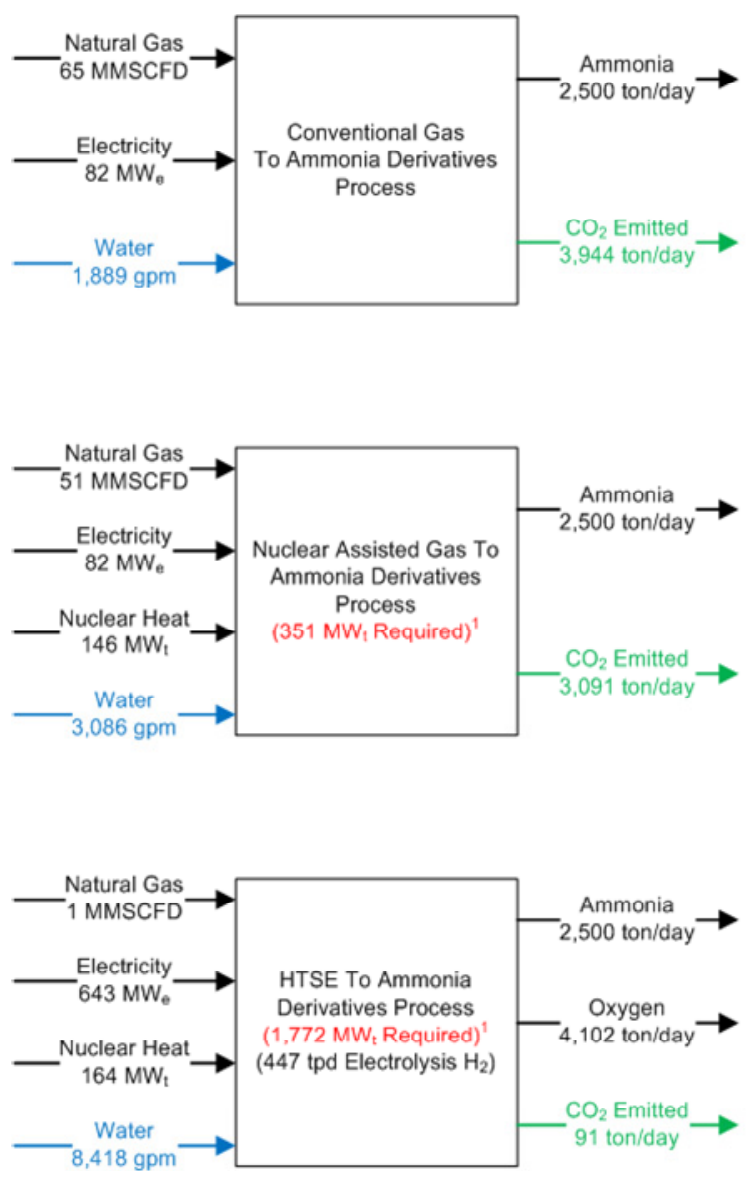

${ }^{1}$ Assumes HTGR power generation efficiency of $40 \%$

Figure 18. Summary of results for use of the HTGR for ammonia production.

Figure 19 summarizes the results of scoping economic comparisons of the two HTGR integrated plants with a conventional ammonia production plant as a function of the costs for $\mathrm{CO}_{2}$ emissions in $\$ /$ ton emitted. The comparison shows the ammonia prices in $\$ /$ ton that would need to be charged to meet the criteria summarized on this figure (e.g., a $15 \%$ internal rate of return on invested equity with a $80 \%$ debtto-equity ratio). The calculations assume a base price of $\$ 6.5 / \mathrm{MMBtu}$ for the natural gas supply.

The use of the HTGR process heat plant as a substitute for some of the burning of natural gas in a conventional plant has pricing that varies in a manner similar to that of the conventional plant (see Figure 19). Because this case only offsets a fraction of the natural gas combustion, the required pricing increases with the costs of carbon emissions at a rate slightly lower than that for the conventional process. The ammonia pricing for the HTGR process heat plant is comparable to that of the conventional plant at costs of $\$ 50 /$ ton of $\mathrm{CO}_{2}$ emissions.

Figure 19 also shows the results for the option wherein the HTGR hydrogen plant supplies pure hydrogen that is combined directly with nitrogen generated from an ASU in the ammonia synthesis reactor. Ammonia pricing for the economic conditions shown in the HTGR hydrogen plant is projected to be comparable to that of the conventional plant at $\mathrm{CO}_{2}$ emission costs of $\sim \$ 160$ /ton. The economics for this case are based on designs and performance of the HTGR and HTSE plants developed in the NGNP Project FY 2007 preconceptual design task. The Project is continuing to support development and optimization of the HTSE process and the full capabilities of the HTGR technology. As these technologies develop the technical and economic viability of the HTGR technology will be revisited and discussed with potential end users. 


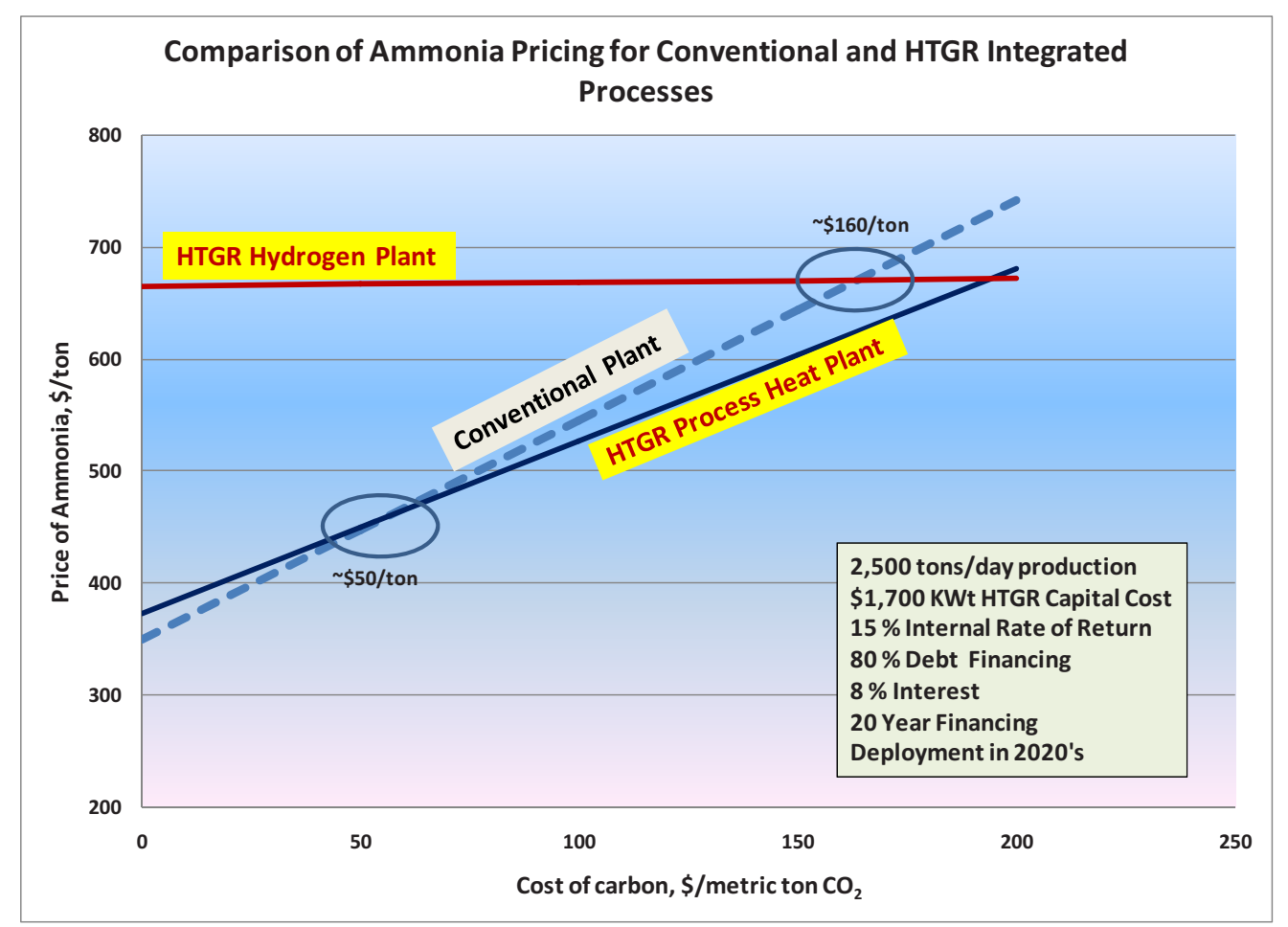

Figure 19. Comparison of conventional and HTGR integrated plant urea pricing versus costs for $\mathrm{CO}_{2}$ emissions.

\subsection{Effect of Uncertainties on Economic Evaluations}

The economics of integrating the HTGR and the HTSE hydrogen plant with the coal-to-MTG and ammonia production processes are very sensitive to the price of hydrogen produced by the HTGR/HTSE plant. The hydrogen price is similarly affected by the assumptions used in the calculation. The economic calculations presented in Figures 14,15 , and 19 reflect a hydrogen price in the $\$ 3.2 / \mathrm{Kg}$ range. This is judged to be representative of current knowledge of the costs and performance of the HTGR and HTSE plants. However, because HTGR design development is still in the preconceptual phase, there is a large uncertainty in the factors applied to calculate this price. To establish the impact of this uncertainty on the price of hydrogen, sensitivity analyses were performed to determine the effect of variations in the principal assumptions applied to calculate this price. The results of these sensitivity analyses are summarized in the tornado chart of Figure 20, which shows the effect of variations in the debt-to-equity ratio, required internal rate of return, plant overnight cost, financing term, operating costs, and interest rates such as interest during construction and financing interest. The variation in each parameter investigated in the sensitivity analyses and the baseline value for each parameter are shown on this chart.

As expected, the first three parameters have the most effect on the results. The total variation shown on the chart ranges from a low of $\$ 2.36 / \mathrm{Kg}$ to a high of $\$ 4.25 / \mathrm{Kg}$, driven by the variation in debt-to-equity ratio investigated (90 to $0 \%$ ). Note that it is not appropriate to sum up all of the extremes shown on a tornado chart to estimate the full range over which the price of hydrogen could vary. These variations will actually combine in a more random way. To provide an assessment of the full range of expected variation in hydrogen pricing for the ranges assumed for the parameters, a Monte-Carlo analysis was performed using triangular distributions of these factors over the ranges shown in Figure 20.

Figure 21 shows the results of this analysis as a probability distribution for the hydrogen price. The mean of the analysis $(\$ 3.18 / \mathrm{Kg})$ conforms well with the baseline price of Figure 20. The wide swing in the 1-sigma span $(\$ 2.69 / \mathrm{Kg}$ to $\$ 3.68 / \mathrm{Kg})$ reflects the large uncertainty in the pricing. 


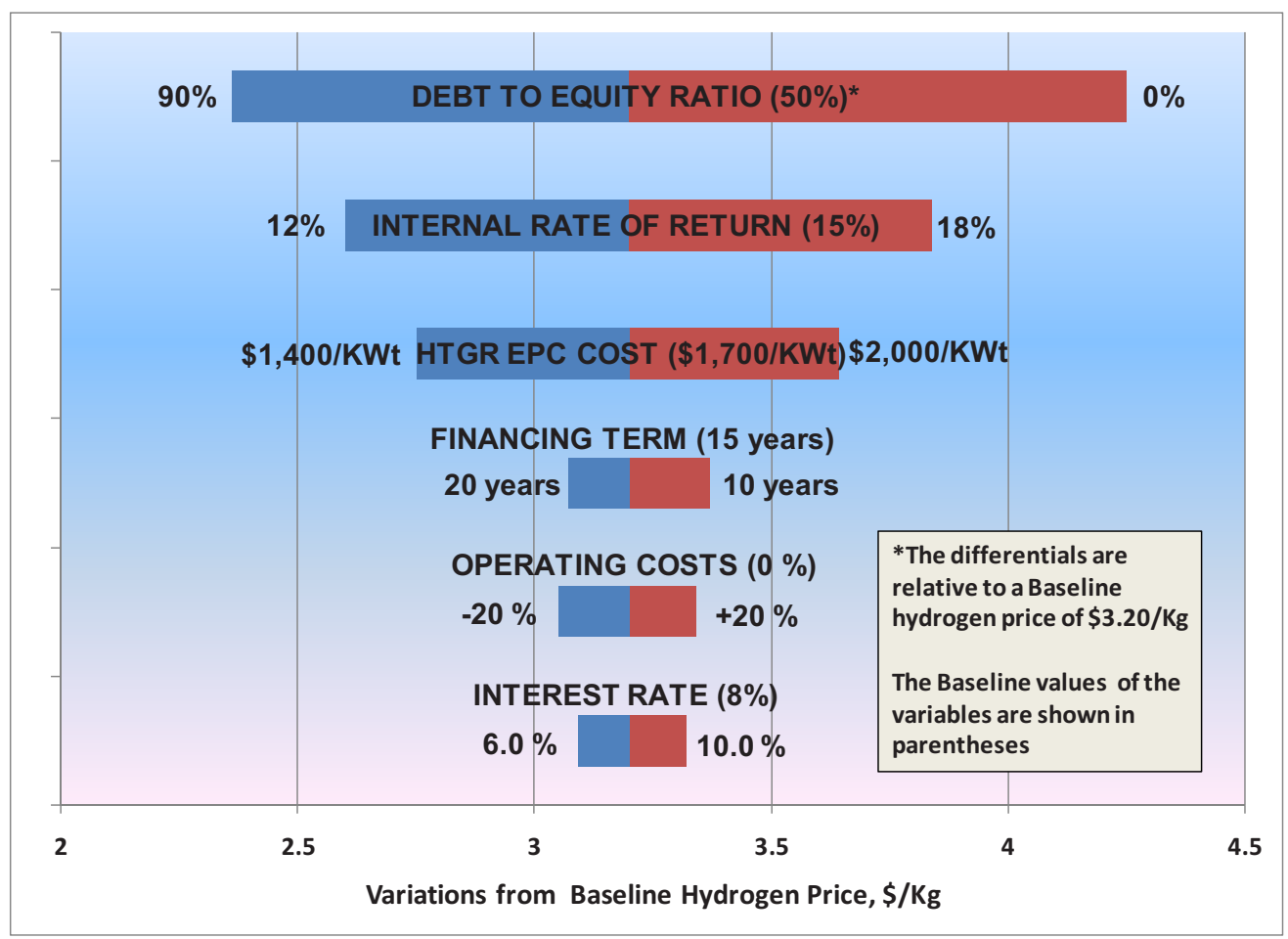

Figure 20. Effect of variations in financial parameters on hydrogen pricing.

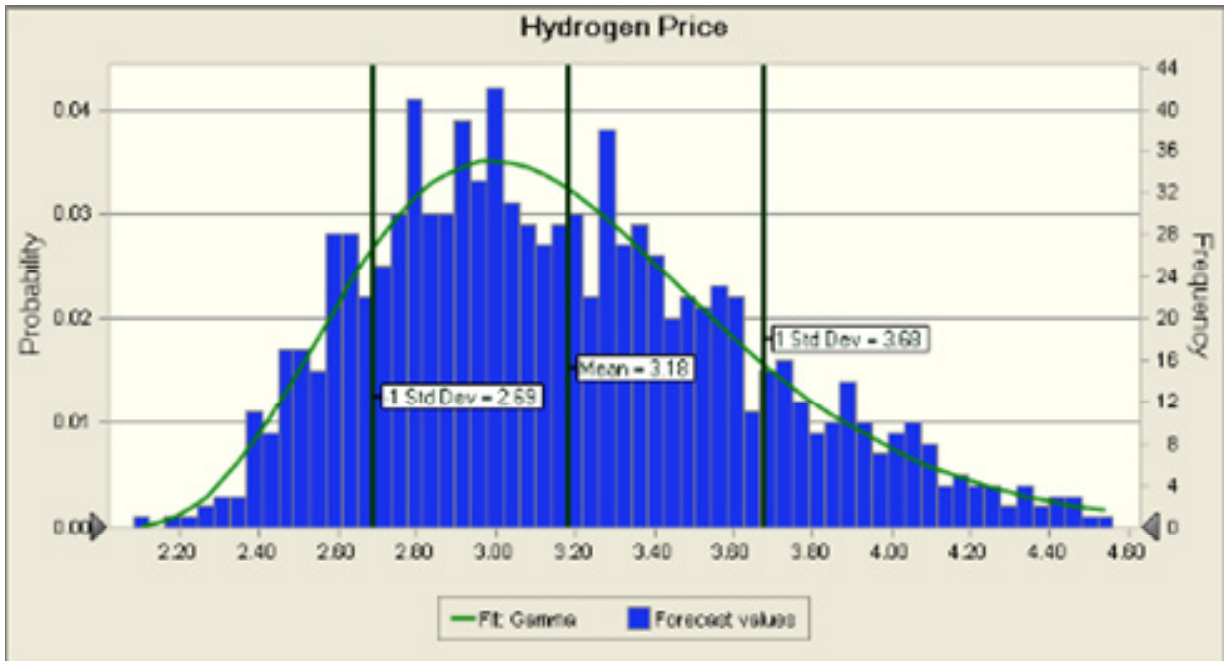

Figure 21. Probability distribution of hydrogen pricing.

As cited previously, the majority of nonrefinery hydrogen is produced using natural gas as the feedstock and energy source in the SMR process. The price of hydrogen using the SMR process is therefore a strong function of the price of natural gas. Figure 22 presents this variation assuming a new SMR process installation, the financial factors used in the economic evaluations presented above, and typical operating costs, excluding the cost of natural gas. The evaluation was completed for a plant generating $\sim 35,000 \mathrm{lb} /$ day of hydrogen with a natural gas usage of $121,000 \mathrm{lb} /$ hour. ${ }^{14}$ The Hydrogen pricing for the SMR process is shown as a function of the price of natural gas ( $\$$ MMBtu) and the cost of carbon emissions ( $\$ / \mathrm{MT}$ of $\left.\mathrm{CO}_{2}\right)$. 


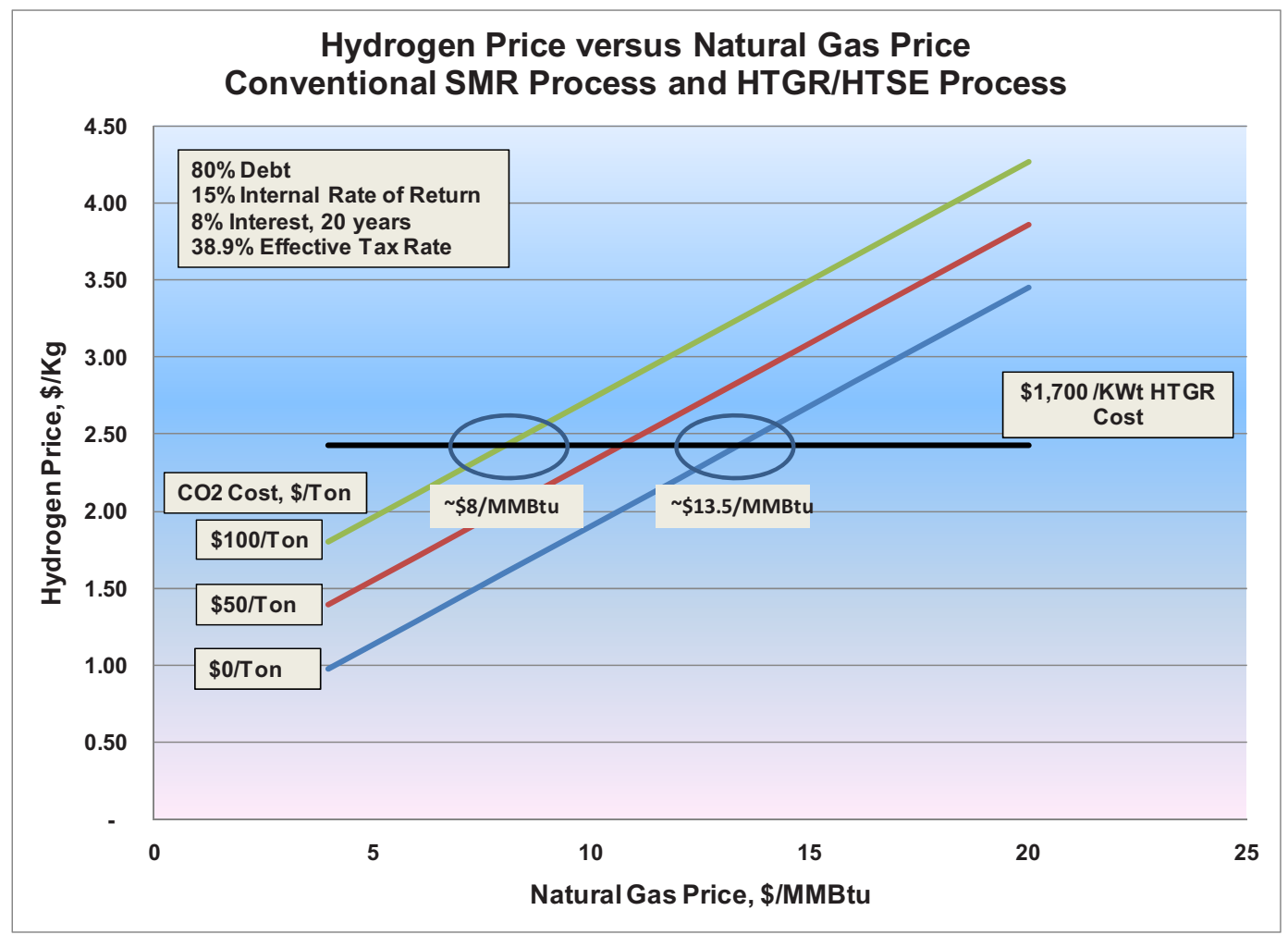

Figure 22. Comparison of hydrogen pricing using SMR and HTGR/HTSE technologies.

The price of hydrogen for the HTGR/HTSE process is for a HTGR plant cost of $\$ 1,700 / \mathrm{kWth}$ and nominal financial factors assumed by the Project for a mature plant installation, (i.e., $80 \%$ debt, $15 \%$ IRR). As shown in Figure 22, the HTGR/HTSE process intersects with the SMR pricing at natural gas prices from $\$ 8 / \mathrm{MMBtu}$ to $\$ 13.5 / \mathrm{MMBtu}$ depending on the cost of carbon emissions.

At the time of this writing the supply to demand ratio of natural gas is sufficient to establish a price at the lower end of the range of prices experienced over the preceding decade. At this price the economics of the HTGR in comparison with a comparable natural gas fired plant are not favorable. However, the supply to demand ratio is trending to support a higher price because of uses of natural gas for base-loaded electricity production and initiation of significant export. These factors will tend to drive the price of natural gas to the point where the HTGR economics are more favorable. It should also be noted that the HTGR technology is slated to become available for commercial application in the mid-2020s and has a design lifetime of 60 years. As shown in Figure 7, over the past 40 years the price of natural gas has shown an average escalation of $2 \%$ above inflation. It is not likely that the price of natural gas will remain at near its current historical low or buck this historical trend in price escalation into the time frame in which the HTGR technology is available for deployment.

\subsection{Conclusion on Application Economics}

To develop confidence in the technical and economic viability of the HTGR technology, the design of the plants needs to be developed to provide better estimates of performance and costs to construct and operate. The economic factors for financing and pricing of energy over the long operating lifetime of HTGR plants need to be refined through further discussions with major financial institutions with an energy portfolio, current nuclear plant owners, and major industrial plants that can benefit from use of energy supplied from the HTGR. Additionally, the long term financial benefit of this technology to the end user has not been quantified in the evaluations performed to-date. The benefits of a long term secure and stable price of energy have been summarized qualitatively in this report. These factors may combine to permit the end user to accept a higher than current market cost that will be stable over the long term. This factor has not been accounted for in economic evaluations of the technology presented in this report. 
How to account for this fact is being pursued with the end users and other stake holders involved in the development of the HTGR technology.

The NGNP Project is developing updated and more refined economic models for evaluating the viability of the business models for both the HTGR plant and the industrial plant for the processes evaluated to-date and for those for which evaluations are to be completed. As the HTGR plant designs evolve, better estimates of the capital and operating costs for these plants will be developed that support higher confidence levels in the results of the economic models. The scoping economic analyses performed to-date do show that the HTGR technology has the potential to be competitive with many conventional industrial processes while offering significant benefit in stabilizing energy prices, providing secure energy sources, and reducing $\mathrm{CO}_{2}$ emissions. The HTGR process may be favored in specific applications if there are governmental regulations that make it more attractive, lower costs and better financing were available, and other factors, such as stability in energy supply and pricing, were major factors.

As the technology develops and as U.S. energy policies and/or direction become better defined, the technical and long term economic viability of the HTGR applications will continue to be reevaluated and reviewed. 


\section{REFERENCES}

1. Demick, L. E., Transforming the U.S. Energy Infrastructure, INL/EXT-09-17436, Idaho National Laboratory, July 2010.

2. MPR-3181, "Survey of HTGR Process Energy Applications," Rev 0, May 2008.

3. AEO, "Annual Energy Outlook 2009 with Projections to 2030," DOE/EIA-0383(2009), March 2009; and, "Assumptions to the Annual Energy Outlook 2009 with Projections to 2030," DOE/EIA0554(2009), March 2009.

4. MPR Associates, "Number of High Temperature Gas-cooled Reactors that Could Hypothetically be Applied to U.S. Hydrogen Production and to Canadian Oil Sands Recovery," MPR Letter Report, August 8, 2008.

5. DOE, The Impact of Increased Use of Hydrogen on Petroleum Consumption and Carbon Dioxide Emissions, SR-OIAF-CNEAF/2008-04, August 2008

6. TEV-693, "Nuclear-Integrated Hydrogen Production Analysis," Idaho National Laboratory, May 15, 2010.

7. CAPP, 2010, Crude Oil Forecast, Markets \& Pipelines, Canadian Association of Petroleum Producers, June 2010.

8. Nelson, L., A. Gribik, V. Maio, M. McKellar, M. Patterson, and R. Wood, Integration of High Temperature Gas-Cooled Reactors into Industrial Process Applications, INL/EXT-09-16942, Idaho National Laboratory, Revision 2, May 2010.

9. NEI, "U.S. Electricity Production Costs and Components, 1995-2008," Nuclear Energy Institute, 2009.

10. H.R. 2454, "Analysis of the American Clean Energy and Security Act of 2009," 111 th Congress, U.S. Environmental Protection Agency, Office of Atmospheric Programs, June 23, 2009.

11. ADMIN, Barack Obama and Joe Biden Policy Paper, "Promoting a Healthy Environment," http://www.barackobama.com/pdf/issues/EnvironmentFactSheet.pdf, Website visited 8/16/2010.

12. S1733, "Clean Energy Jobs and American Power Act of 2009," Congressional Budget Office, December 2009.

13. Sandia, "FY09 Projected Hydrogen Cost Estimates for Nuclear Hydrogen Initiative Baseline Processes," S and 2009-6630P, December 2009.

14. DOE, 2008, "Current (2005) Hydrogen from Natural Gas without CO2 Capture and Sequestration," Excel File, U.S. DOE/NETL, May 2008. 